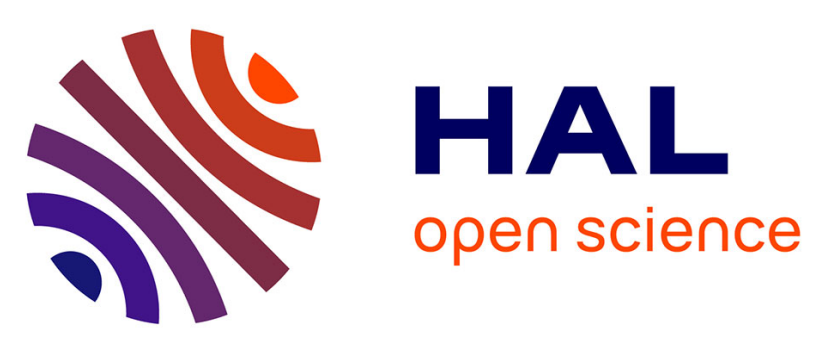

\title{
Correlation between microstructure and intergranular corrosion behavior of low delta-ferrite content AISI 316L aged in the range 550-700 $\mathrm{C}$
}

\author{
A Ben Rhouma, T Amadou, H Sidhom, C Braham
}

\section{- To cite this version:}

A Ben Rhouma, T Amadou, H Sidhom, C Braham. Correlation between microstructure and intergranular corrosion behavior of low delta-ferrite content AISI 316L aged in the range 550-700 C. Journal of Alloys and Compounds, 2017, 708, pp.871-886. 10.1016/j.jallcom.2017.02.273 . hal-01638576

\author{
HAL Id: hal-01638576 \\ https://hal.science/hal-01638576
}

Submitted on 20 Nov 2017

HAL is a multi-disciplinary open access archive for the deposit and dissemination of scientific research documents, whether they are published or not. The documents may come from teaching and research institutions in France or abroad, or from public or private research centers.
L'archive ouverte pluridisciplinaire HAL, est destinée au dépôt et à la diffusion de documents scientifiques de niveau recherche, publiés ou non, émanant des établissements d'enseignement et de recherche français ou étrangers, des laboratoires publics ou privés. 


\title{
Correlation between microstructure and intergranular corrosion behavior of low delta-ferrite content AISI 316L aged in the range $550-700{ }^{\circ} \mathrm{C}$
}

\author{
A. Ben Rhouma a ${ }^{\text {a }}$ T. Amadou ${ }^{\text {a }}$, H. Sidhom ${ }^{\text {a, }}{ }^{,}$, C. Braham ${ }^{\text {b }}$ \\ ${ }^{a}$ Laboratoire de Mécanique, Matériaux et Procédés (LR99ES05), Université de Tunis, ENSIT, 5 AV Taha Hussein Montfleury, 1008 Tunis, Tunisia \\ ${ }^{\mathrm{b}}$ Laboratoire Procédés et Ingénierie en Mécanique et Matériaux (PIMM, CNRS UMR 8006), ENSAM, 151 Bd de l'Hôpital, 75013 Paris, France
}

Keywords:

Austenitic stainless steel

AISI 316L

ICG

Aging

Sensitization

Microstructure

\begin{abstract}
A B S T R A C T
The microstructure and the phase identification of austenitic stainless steel AISI 316L with low $\delta$-ferrite content $(\delta \leq 1 \%)$ and aged for up to $80000 \mathrm{~h}$ at temperatures ranging from 550 to $700{ }^{\circ} \mathrm{C}$ were investigated by using an optical microscope (OM), a scanning electron microscope (SEM) and a transmission electron microscope (TEM). Local changes of chromium content, resulting from nucleation and growth of chromium-rich phases during aging, were quantitatively assessed by energy dispersive X-ray spectroscopy (EDX) in the scanning transmission electron microscope (STEM). The intergranular corrosion behavior (IGC) of annealed and aged specimens was evaluated using the double loop electrochemical potentiokinetic reactivation (DL-EPR) and completed by IGC morphologies according to the ASTM A262 practice A standard.

The results showed that $\delta$-ferrite decomposed gradually into $\mathrm{M}_{23} \mathrm{C}_{6}$ at $550{ }^{\circ} \mathrm{C}$ and decomposed totally into intermetallic phases $\left(\sigma, \eta, \chi\right.$, and R) and into secondary austenite $\left(\gamma_{\mathrm{r}}\right)$ at temperatures equal to or higher than $650{ }^{\circ} \mathrm{C}$. Similarly $\gamma$-austenite decomposed into $\mathrm{M}_{23} \mathrm{C}_{6}$ carbide at $550{ }^{\circ} \mathrm{C}$ and into intermetallic phases such as $\eta$ and $\sigma$ in addition to carbide, at higher temperatures. The time-temperaturesensitization diagram (TTS) was established and used to calculate the critical cooling rate (CCR) that prevents IGC sensitization. The analysis of IGC results leads to the conclusion that sensitizationdesensitization is still controlled by the characteristics of chromium-depleted area surrounding austenite grain boundary regions. No significant effect of remained $\delta$-ferrite and derived components on the corrosion behavior of AISI 316 L containing $1 \%$ of $\delta$-ferrite.
\end{abstract}

\section{Introduction}

Austenitic stainless steels are usually recommended for applications requiring high corrosion resistance materials. This property is due to the chromium content that is equal to or higher than $16 \mathrm{wt}$ $\%$ that forms a self-healing protective film on the surface. However, these materials have modest low-temperature mechanical strength and they are recurred for high temperature application such as in nuclear power plants where they are used in sea water cooling pumps and steam generators. Moreover, these materials are currently used in more severe environments such as offshore platforms [1], food, chemical industries and medical application [2-5] due to their good toughness at a large temperature range [6] and to their resistance to pitting corrosion [4,7-9].
Despite the various attempts to enhance the corrosion resistance of these austenitic stainless steels [10-27], their susceptibility to hot cracking during cooling from welding [18,28] and their sensitivity to IGC during isothermal heating or continuous cooling after heating through the sensitization temperature ranging from 500 to $800{ }^{\circ} \mathrm{C}[16,20,29-33]$ remain unsolved. The state of the literature knowledge indicates that the convenient and commonly used method to prevent hot cracking consists in introducing a small amount of $\delta$-ferrite in austenitic stainless steel [34-36]. It has been reported that a $\delta$-ferrite fraction ranging from $1 \%$ to $6 \%$ is efficient to avoid hot cracking in the welded austenitic stainless steels. It also decreases the crack growth rate in SCC $[34,35,37]$. As for the susceptibility to intergranular corrosion, it was reported that after welding, cooling at a rate above the CCR prevents the sensitization to IGC. Therefore some values of CCR, depending on the microstructure and chemical composition, were provided [13]. Analysis 
of literature data provided by various methods and tests [38-45] reveals the great influence of microstructure and chemical composition of austenitic steel on the IGC sensitivity and CCR. According to Sidhom et al. [44], the IGC sensitization was related to chromium-depleted areas resulting from $\mathrm{M}_{23} \mathrm{C}_{6}$ carbide precipitation during aging at temperatures ranging from $550^{\circ} \mathrm{C}$ to $750{ }^{\circ} \mathrm{C}$ of the fully austenitic stainless steel type AISI 316L. Moreover, it was shown that the IGC sensitization-desensitization was controlled by the chromium level and by the width of the chromium depleted area. Similarly, Yae Kina et al. [27] studied the intergranular behavior of AISI 304 with low ferrite content during aging at $650{ }^{\circ} \mathrm{C}$ and $750{ }^{\circ} \mathrm{C}$, and showed that $\delta$-ferrite transformation to $\sigma$-phase does not occur for periods of up to $200 \mathrm{~h}$. They attributed the sensitization phenomenon to $\mathrm{M}_{23} \mathrm{C}_{6}$ carbides and reported that the material has healed after $48 \mathrm{~h}$ at $750{ }^{\circ} \mathrm{C}$ but has not healed at $650{ }^{\circ} \mathrm{C}$ due to the thermally active bulk chromium diffusion process. Moreover, authors indicated that $\delta$-ferrite remained stable during aging for periods of up to $200 \mathrm{~h}$ at $750^{\circ} \mathrm{C}$. However, Guanshun et al. [46] have shown that the $\delta$-ferrite in Ti-modified super $304 \mathrm{H}$ decomposes rapidly into $\sigma$-phase, $\mathrm{M}_{23} \mathrm{C}_{6}$ carbides and secondary austenite during aging at $650{ }^{\circ} \mathrm{C}$ for periods of $4 \mathrm{~h}-500 \mathrm{~h}$. These phases strongly influence the IGC resistance of the steel. They added that IGC sensitization at $650{ }^{\circ} \mathrm{C}$ of the studied material is associated basically with the $\sigma$-phase. In addition, they also established that higher fractions of $\delta$-ferrite increase the IGC sensitization at $650{ }^{\circ} \mathrm{C}$. Moreover, in the case of welded joints of austenitic stainless steels Garcia et al. [47] showed that the DOS of different welding zones has been correlated with the local changes in the material composition and its microstructure caused by the welding process. They showed that $\sigma$-phase, formed by the transformation of the $\delta$-ferrite, contributed to the IGC sensitization of welded joints but less than the segregation phenomenon related to dendritic structure.

Despite the several studies devoted to the effect of small amounts of $\delta$-ferrite on the IGC sensitization of austenitic stainless steel, some aspects are still unsolved:

- Even though the instability of $\delta$-ferrite is evident, its decomposition process during heating and the associated quantitative depletion of chromium are still lacking for the comprehensive understanding of its effect on the corrosion behavior of austenitic stainless steel containing $\delta$-ferrite.

- The decomposition of $\delta$-ferrite has been often studied at relatively high temperatures such as 650 and $750{ }^{\circ} \mathrm{C}$ for relatively short aging periods of up to $500 \mathrm{~h}[27,46]$. These conditions promote the $\sigma$-phase formation that generates less deep chromium depletion. Moreover, at this temperature range, the rapid bulk chromium diffusion enhances the healing process and IGC phenomena could then be concealed. Therefore, the conclusions related to the studied temperature range could not be valid for lower temperatures such as 600 and $550{ }^{\circ} \mathrm{C}$ and for very high aging durations due to other possible $\delta$-ferrite decomposition mechanisms involving carbide precipitation.

- The effect of $\delta$-ferrite transformation on the TTS diagram and the CCR has not yet been fully resolved due to the lack of a systematic study exploring a large range of sensitization temperatures.
- There is no predictive tool of IGC sensitization-desensitization to make extrapolation of DOS reliable for longer aging times at lower temperatures from short aging periods at higher temperature results.

To provide answers to the above raised issues, the microstructural evolution and the intergranular corrosion behavior of AISI 316L containing $1 \%$ of $\delta$-ferrite during aging for periods varying from $50 \mathrm{~h}$ to $80000 \mathrm{~h}$ at temperatures ranging from 550 to $700{ }^{\circ} \mathrm{C}$ are worth investigating. The $1 \% \delta$-ferrite content has been recommended by the nuclear boiler manufacturer, in order to avoid hot cracking and brittle sigma phase resulting from welding of austenitic stainless steel AISI 316L. It is therefore of considerable importance to identify the decomposition of ferrite and austenite during the aging process and to quantify the associated chromium depletion in order to understand their specific effects on the intergranular corrosion behavior. Secondly, the DOS corresponding to various aging conditions has been established using an electrochemical DL-EPR test, and correlated with the microstructural changes and with the chromium depletion area characteristics in order to deduce the IGC sensitization-desensitization criteria. Then, the TTS diagram was established and correlated with the TTP diagram in order to identify the role of phase decomposition on the IGC sensitization. The critical cooling rate avoiding IGC sensitization was calculated. Finally the effect of $\delta$-ferrite on the intergranular corrosion behavior was discussed by superimposing TTS diagrams corresponding to stainless steels with different ferrite contents.

\section{Material and aging conditions}

The investigated material is an austenitic stainless steel type AISI 316L with a low carbon content $\mathrm{C}=0.023 \mathrm{wt} \%$. The chemical composition of the steel is given in Table 1 . The test specimens were cut from a $30 \mathrm{~mm}$ thick hot-rolled plate. In the as received state, the samples underwent two annealing treatments by water quenching subsequent to holding at $1070{ }^{\circ} \mathrm{C}$ for $1 \mathrm{~h}$. Aging treatments were carried out on the annealed samples at temperatures ranging from 550 to $700{ }^{\circ} \mathrm{C}$ for a short duration such as $50 \mathrm{~h}$ as well as for a very long duration of up to $80000 \mathrm{~h}$.

\section{Tests and methods}

\subsection{Microstructure investigation techniques}

The ferrite content of austenitic stainless steel was evaluated by measurements using Feritoscope type FMP 30. Microstructure investigations were carried out on the annealed and aged specimens before and after corrosion tests through using O. M, SEM and TEM. $\mathrm{O}$. M and SEM examinations were conducted on samples polished using fine silicon carbide papers (180-2000 grades) then polished with $6 \mu \mathrm{m}$ water-based diamond suspension and finally electrochemically polished in $10 \%$ oxalic acid solution in order to reveal the microstructure. The TEM observations were performed on thin foils with $3 \mathrm{~mm}$ diameter thinned by electro-polishing in a glycol ethylene solution cooled to $273 \mathrm{~K}\left(0^{\circ} \mathrm{C}\right)$. Second phases formed during aging were identified by electron diffraction patterns carried

Table 1

Chemical composition of the AISI 316L (wt. \%).

\begin{tabular}{|c|c|c|c|c|c|c|c|c|c|c|c|c|c|}
\hline Elements & $\mathrm{C}$ & $S$ & $\mathrm{P}$ & $\mathrm{Si}$ & $\mathrm{Mn}$ & $\mathrm{Ni}$ & $\mathrm{Cr}$ & Mo & $\mathrm{Ti}$ & $\mathrm{Nb}$ & $\mathrm{Cu}$ & $\mathrm{N}$ & $\mathrm{B}(\mathrm{ppm})$ \\
\hline AISI 316L & 0.023 & 0.008 & 0.029 & 0.4 & 1.7 & 12.1 & 17.4 & 2.44 & $<0.01$ & - & 0.17 & 0.078 & 38 \\
\hline
\end{tabular}


out on thin foils using an EM 430 Philips transmission electron microscope using $300 \mathrm{keV}$ accelerating voltage. Their chemical composition was determined by EDX conducted on the carbon extractive replica in the STEM equipped with EDAX microanalysis hardware. Meanwhile, X-Ray microanalysis conducted on the thin foils was used to assess the evolution of chromium content of the depleted areas adjacent to $\gamma / \gamma$ grain boundaries and in the $\delta$-ferrite islands during aging.

\subsection{Double loop electrochemical potentiokinetic reactivation tests and intergranular corrosion morphologies}

The susceptibility to intergranular corrosion of the aged AISI 316L SS with low $\delta$-ferrite content was evaluated using the double loop electrochemical potentiokinetic reactivation (DL-EPR) tests conducted in a conventional three-electrode cell. The working electrode was the sample which is cut in the rolling direction (RD) in order to evaluate the reactivity of the surface with a representative $\delta$-ferrite content of the sheet (1\%). The auxiliary and the reference electrodes were Pt and saturated calomel (SCE) respectively. Tests were carried out in an appropriate electrolyte consisting of $0.5 \mathrm{M} \mathrm{H}_{2} \mathrm{SO}_{4}+0.01 \mathrm{M} \mathrm{NH}_{4} \mathrm{SCN}$ at a temperature of $25^{\circ} \mathrm{C}$. The potential was varied from an active $(-400 \mathrm{mV} / \mathrm{ECS})$ to a passive $(+200 \mathrm{mV} / \mathrm{ECS})$ domain with a scan rate equal to $1 \mathrm{mV} / \mathrm{s}$. These test conditions were previously qualified as optimal to evaluate quantitatively the DOS of austenitic stainless steel grades $[44,45]$. The DOS was evaluated by the reactivation ratio (Ir/Ia\%) where Ir is the reactivation (cathodic) current density peak and Ia is the activation (anodic) current density one. A ratio equal to or higher than $1 \%$ indicates that sensitization to IGC of the tested sample is confirmed by intergranular attacks (Fig. 1). The result of DL-EPR tests were completed by IGC morphology according to ASTM A262 (practice A) [38].

\section{Results}

\subsection{Microstructural analysis}

\subsubsection{Annealed microstructure}

The microstructure in the annealed state consists of islands of $\delta$ ferrite aligned in the rolling direction of the sheet in an austenitic matrix with a grain size ranging from 70 to $100 \mu \mathrm{m}$. In the micrograph, the dark phase is that of the $\delta$-ferrite whereas the bright one is that of the $\gamma$ austenite (Fig. 2a). The volume fraction of $\delta$-ferrite, assessed by the ferritoscope, was around $1 \%$. The annealed microstructure is clearly free from intergranular $\gamma / \gamma$ and $\delta / \gamma$ interface precipitations as shown in TEM micrographs (Fig. 2b and c).

\subsubsection{Aged microstructure}

SEM examinations of aged specimens reveal a rapid decomposition of $\delta$-ferrite comparatively to $\gamma$ austenite during aging at temperatures ranging from 550 to $700{ }^{\circ} \mathrm{C}$. Indeed, SEM micrographs showed precipitates at the $\delta / \gamma$ interfaces while there was no visible precipitates at the $\gamma / \gamma$ grain boundaries after aging at $550{ }^{\circ} \mathrm{C}$ for $1000 \mathrm{~h}$ (Fig. 3a). As aging at $550{ }^{\circ} \mathrm{C}$ continued from $1000 \mathrm{~h}$ to $10000 \mathrm{~h}$, precipitates grew substantially inside the $\delta$-ferrite islands

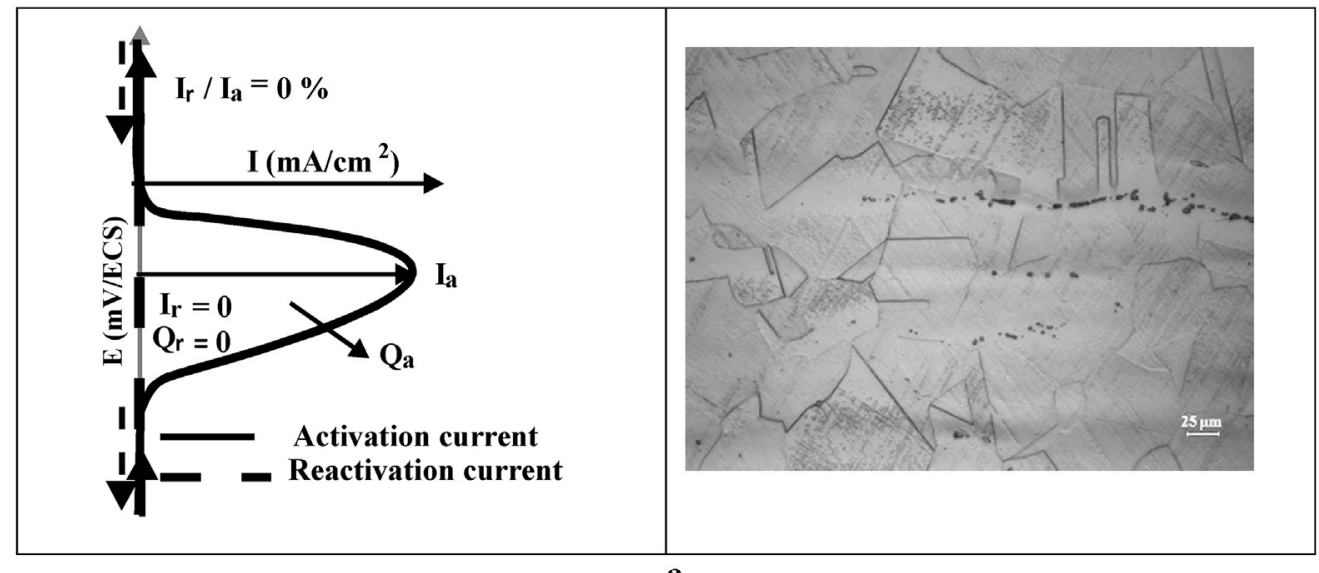

$\mathbf{a}$

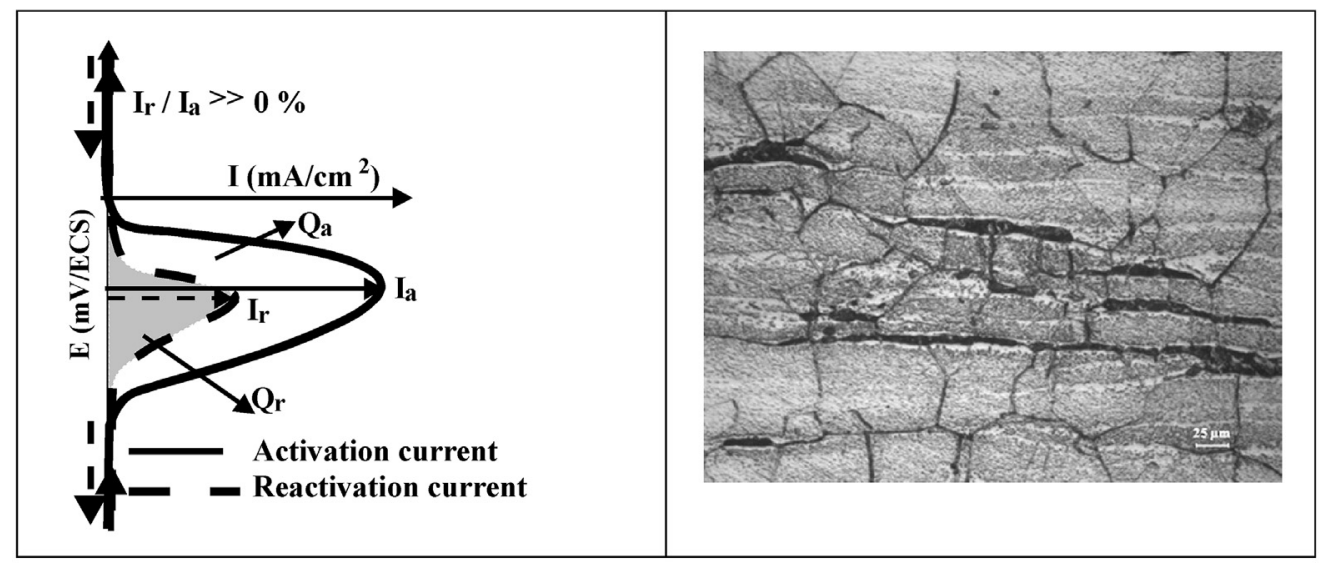

b

Fig. 1. DL-EPR responses and IGC sensitization criterion: (a) unsensitized material $\left(\mathrm{I}_{\mathrm{r}} / \mathrm{I}_{\mathrm{a}}<1 \%\right.$ ); (b) sensitized material $\left(\mathrm{I}_{\mathrm{r}} / \mathrm{I}_{\mathrm{a}} \geq 1 \%\right.$ ). 


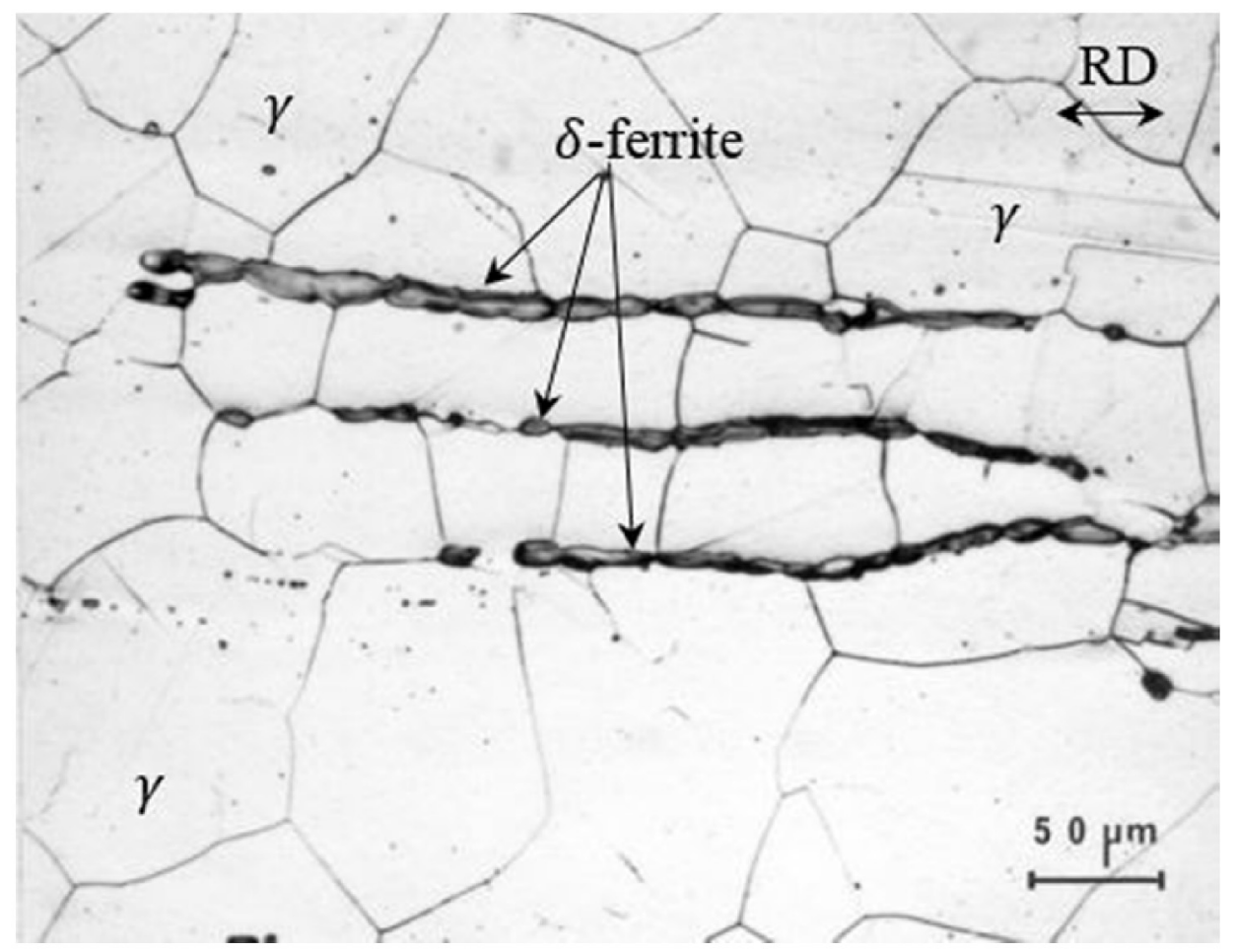

$\mathbf{a}$
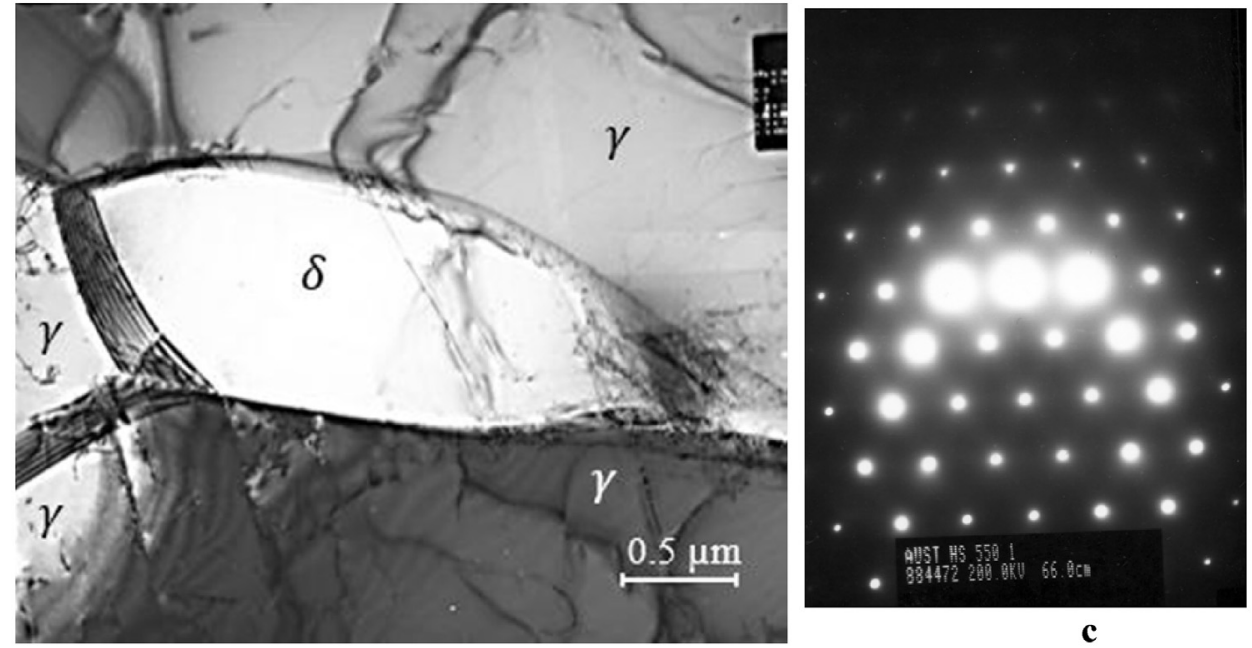

b

Fig. 2. Microstructure of annealed AISI 316 L: (a) Ferrite islands (optical micrograph); (b) $\delta$ ferrite grain (TEM micrograph); (c) SAD of ferrite, [111] $\delta$.

whereas the first generative precipitate was observed at $\gamma / \gamma$ grain boundaries (Fig. 3b). After higher aging duration such as $30000 \mathrm{~h}$, the typical eutectoid microstructure was observed inside the $\delta$ ferrite islands (Fig. 3c) and the intergranular $\gamma / \gamma$ precipitates encountered more austenite grains (Fig. 3d). Aging at higher temperatures, such as 600 and $650{ }^{\circ} \mathrm{C}$, accelerates substantially the decomposition processes into $\delta$ and $\gamma$ phases. Aging at $650{ }^{\circ} \mathrm{C}$ for $30000 \mathrm{~h}$ leads to the total decomposition of $\delta$-ferrite (Fig. 3e) and enhances the precipitates coarsening at the boundaries and inside austenite grains (Fig. 3f). These observations imply that the higher the aging temperature, the faster the decomposition of both ferrite and austenite phases due to the involved thermally active diffusion processes.

The TEM examination and the related selected area diffraction (SAD) have been used to identify the second phases formed during aging on the basis of crystalline structure analysis. The results summarized in Table 2 provide more information related to the effect of aging time and temperature on the microstructure evolution including precipitation sequences and sites. It can be inferred that the microstructural changes occurred easily in the $\delta / \gamma$ interfaces by the nucleation of a metastable intermetallic phase after a few hundred hours of aging at $550{ }^{\circ} \mathrm{C}$ (Fig. $4 \mathrm{a}$ and b). This phase was firstly assumed by Sidhom et al. [48] to be an icosahedral structure on the basis of typical SAD shown in Fig. 4b. Whilst, Carron et al. [49] have attributed this crystalline structure to the stacking faulted Frank Kaspar phases. After $1000 \mathrm{~h}$ at $550{ }^{\circ} \mathrm{C}$, in addition to Frank Kaspar phases, $\mathrm{M}_{23} \mathrm{C}_{6}$ chromium carbides nucleated at the $\delta / \gamma$ interfaces and grew into $\delta$ ferrite (Fig. 4a and c). As the aging time increased to up $10000 \mathrm{~h}$ at $550{ }^{\circ} \mathrm{C}, \delta$-ferrite was transformed gradually into $\mathrm{M}_{23} \mathrm{C}_{6}$ chromium carbides and into a 

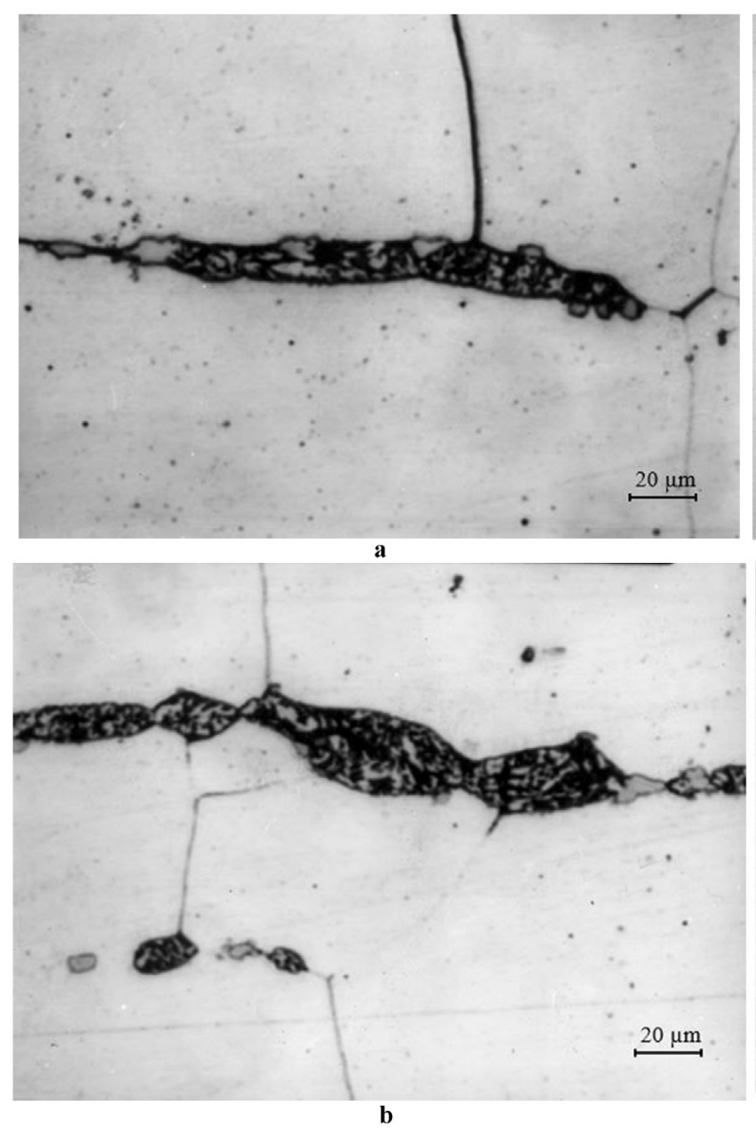

b
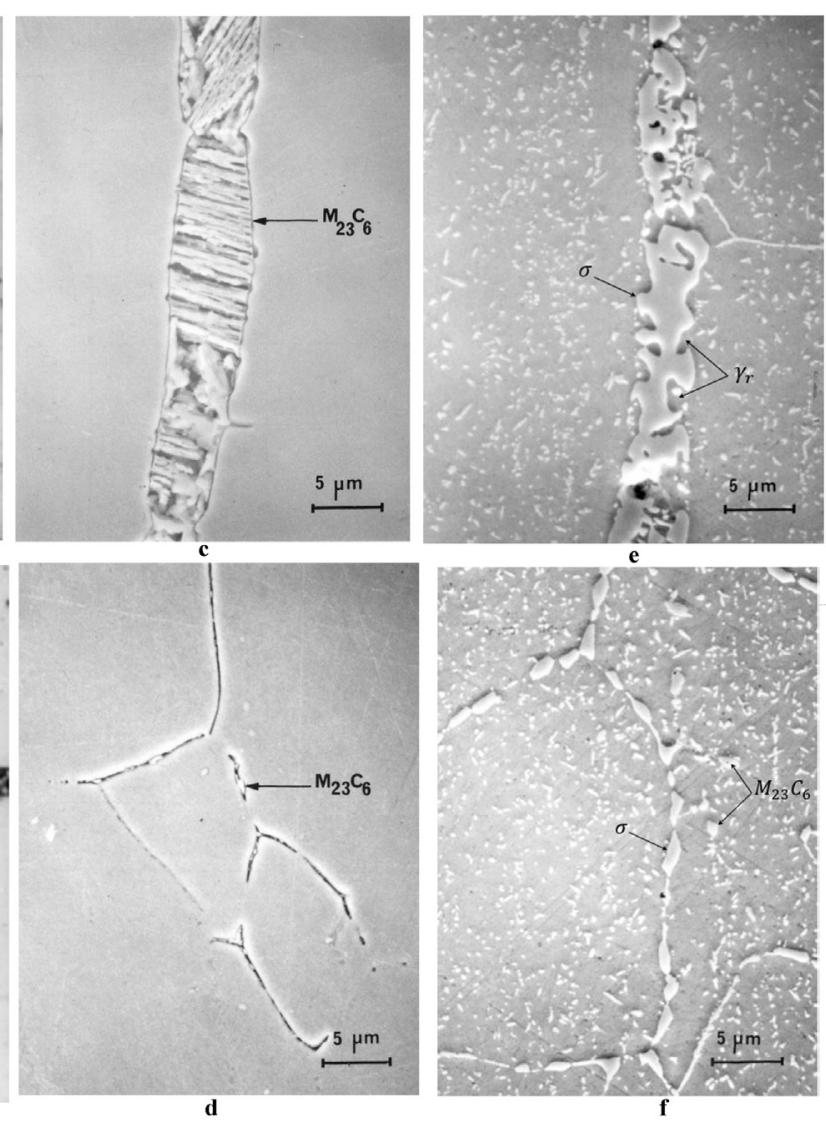

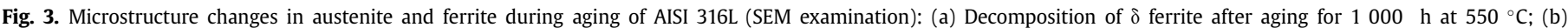

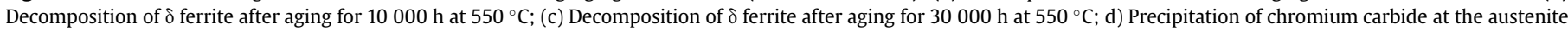

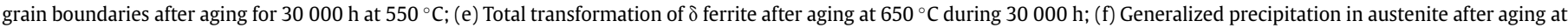
$650{ }^{\circ} \mathrm{C}$ during $30000 \mathrm{~h}$.

Table 2

Carbides and intermetallic phases formed during aging of AISI 316L (TEM identification)

\begin{tabular}{|c|c|c|c|c|c|c|}
\hline \multirow[t]{2}{*}{$\mathrm{T}\left({ }^{\circ} \mathrm{C}\right)$} & \multirow[t]{2}{*}{ Sites of Precipitation } & \multicolumn{5}{|l|}{$t(h)$} \\
\hline & & 100 & 1000 & 10000 & 30000 & 80000 \\
\hline \multirow[t]{4}{*}{550} & $\delta / \gamma$ & F.K phase & F.K phase, $\mathrm{M}_{23} \mathrm{C}_{6}$ & $\mathrm{M}_{23} \mathrm{C}_{6}$ & $\mathrm{M}_{23} \mathrm{C}_{6}$ & $\mathrm{M}_{23} \mathrm{C}_{6}$ \\
\hline & $\delta$ & & F.K phase, $\mathrm{M}_{23} \mathrm{C}_{6}$ & $\mathrm{M}_{23} \mathrm{C}_{6,}, \gamma_{\mathrm{r}}$ & $\mathrm{M}_{23} \mathrm{C}_{6}, \gamma_{\mathrm{r}}$ & $\mathrm{M}_{23} \mathrm{C}_{6}, \gamma_{\mathrm{r}}$ \\
\hline & $\gamma / \gamma$ & - & - & $\mathrm{M}_{23} \mathrm{C}_{6}$ & $\mathrm{M}_{23} \mathrm{C}_{6}$ & $\mathrm{M}_{23} \mathrm{C}_{6}$ \\
\hline & $\gamma$ & - & - & $\mathrm{M}_{23} \mathrm{C}_{6}$ & $\mathrm{M}_{23} \mathrm{C}_{6}$ & $\mathrm{M}_{23} \mathrm{C}_{6}$ \\
\hline \multirow[t]{4}{*}{600} & $\delta / \gamma$ & F.K phase, $\mathrm{M}_{23} \mathrm{C}_{6}$ & $\mathrm{M}_{23} \mathrm{C}_{6}$ & $\mathrm{M}_{23} \mathrm{C}_{6, \eta} \eta$ & $\mathrm{M}_{23} \mathrm{C}_{6}, \eta, \sigma$ & n.e \\
\hline & $\delta$ & $\mathrm{M}_{23} \mathrm{C}_{6}$ & $\mathrm{M}_{23} \mathrm{C}_{6}, \gamma_{\mathrm{r}}$ & $\mathrm{M}_{23} \mathrm{C}_{6}, \gamma_{\mathrm{r}}$ & $\mathrm{M}_{23} \mathrm{C}_{6}, \gamma_{\mathrm{r}}$ & n.e \\
\hline & $\gamma / \gamma$ & - & $\mathrm{M}_{23} \mathrm{C}_{6}$ & $\mathrm{M}_{23} \mathrm{C}_{6}, \eta$ & $\mathrm{M}_{23} \mathrm{C}_{6}, \eta$ & n.e \\
\hline & $\gamma$ & - & $\mathrm{M}_{23} \mathrm{C}_{6}$ & $\mathrm{M}_{23} \mathrm{C}_{6}, \eta$ & $\mathrm{M}_{23} \mathrm{C}_{6}, \eta$ & n.e \\
\hline \multirow[t]{6}{*}{650} & $\delta / \gamma$ & F.K phase, $\mathrm{M}_{23} \mathrm{C}_{6}$ & $\mathrm{M}_{23} \mathrm{C}_{6}, \eta$ & $\delta$ & $\delta$ & $\delta$ \\
\hline & & & & $\mathrm{M}_{23} \mathrm{C}_{6}, \eta, \sigma, \chi, \mathrm{R}$ & $\mathrm{M}_{23} \mathrm{C}_{6}, \eta, \sigma, \chi, \mathrm{R}$ & $\eta, \sigma, \chi, R$ \\
\hline & $\delta$ & $\mathrm{M}_{23} \mathrm{C}_{6}, \gamma_{\mathrm{r}}$ & $\mathrm{M}_{23} \mathrm{C}_{6}, \gamma_{\mathrm{r}}$ & $\oint$ & $\oint$ & $\delta$ \\
\hline & & & & $\mathrm{M}_{23} \mathrm{C}_{6}, \gamma_{\mathrm{r},}, \eta, \sigma, \chi, \mathrm{R}$ & $\gamma_{\mathrm{r},} \eta, \sigma, \chi, \mathrm{R}$ & $\gamma_{\mathrm{r},} \eta, \sigma, \chi, \mathrm{R}$ \\
\hline & $\gamma / \gamma$ & $\mathrm{M}_{23} \mathrm{C}_{6}$ & $\mathrm{M}_{23} \mathrm{C}_{6}, \eta$ & $\mathrm{M}_{23} \mathrm{C}_{6}, \eta, \sigma$ & $\mathrm{M}_{23} \mathrm{C}_{6}, \eta, \sigma, \chi$ & $\eta, \sigma, \chi$ \\
\hline & $\gamma$ & - & $\mathrm{M}_{23} \mathrm{C}_{6}, \eta$ & $\mathrm{M}_{23} \mathrm{C}_{6}, \eta$ & $\mathrm{M}_{23} \mathrm{C}_{6}, \eta, \sigma, \chi$ & $\mathrm{M}_{23} \mathrm{C}_{6}, \eta, \sigma, \chi$ \\
\hline \multirow[t]{4}{*}{700} & $\delta / \gamma$ & $\mathrm{M}_{23} \mathrm{C}_{6}$ & $\sigma, \gamma_{\mathrm{r}}$ & $\delta$ & n.e & n.e \\
\hline & $\delta$ & $\mathrm{M}_{23} \mathrm{C}_{6}, \gamma_{\mathrm{r}}$ & $\sigma, \gamma_{\mathrm{r}}$ & $\delta$ & n.e & n.e \\
\hline & $\gamma / \gamma$ & $\mathrm{M}_{23} \mathrm{C}_{6}, \eta$ & $\mathrm{M}_{23} \mathrm{C}_{6}, \eta, \sigma$ & $\mathrm{M}_{23} \mathrm{C}_{6}, \eta, \sigma$ & n.e & n.e \\
\hline & $\gamma$ & $\mathrm{M}_{23} \mathrm{C}_{6}$ & $\mathrm{M}_{23} \mathrm{C}_{6}, \eta$ & $\mathrm{M}_{23} \mathrm{C}_{6}, \eta, \sigma$ & n.e & n.e \\
\hline
\end{tabular}

-: no precipitate.

n.e: no examined.

F.K: Frank Kaspar phase.

$\eta$ : Laves phase.

$\gamma_{\mathrm{r}}$ : Regenered austenite.

$\S$ : Total decomposition of $\delta$ ferrite. 
regenerated austenite $\left(\gamma_{r}\right)$ (Fig. 5a and b), while a small number of carbides appeared at the $\gamma / \gamma$ grain boundaries (Fig. 5c). There was no other second phase formed until $80000 \mathrm{~h}$ at $550{ }^{\circ} \mathrm{C}$, while the carbides coarsened substantially into $\delta$-ferrite (Fig. 6a) at the $\gamma / \gamma$ grain boundaries and in the dislocation pull ups into $\gamma$ grains (Fig. 6b). However, it is important to notice that, at $550^{\circ} \mathrm{C}$, when the aging time is extended, the Frank Kaspar phase disappears in favor of $\mathrm{M}_{23} \mathrm{C}_{6}$ carbides and the $\delta$-ferrite is not totally transformed after aging for up to $80000 \mathrm{~h}$.

Aging at a higher temperature such as $650{ }^{\circ} \mathrm{C}$ promotes the precipitation of various intermetallic phases in addition to $\mathrm{M}_{23} \mathrm{C}_{6}$ carbides. The precipitation sequences occurred firstly at the $\delta / \gamma$

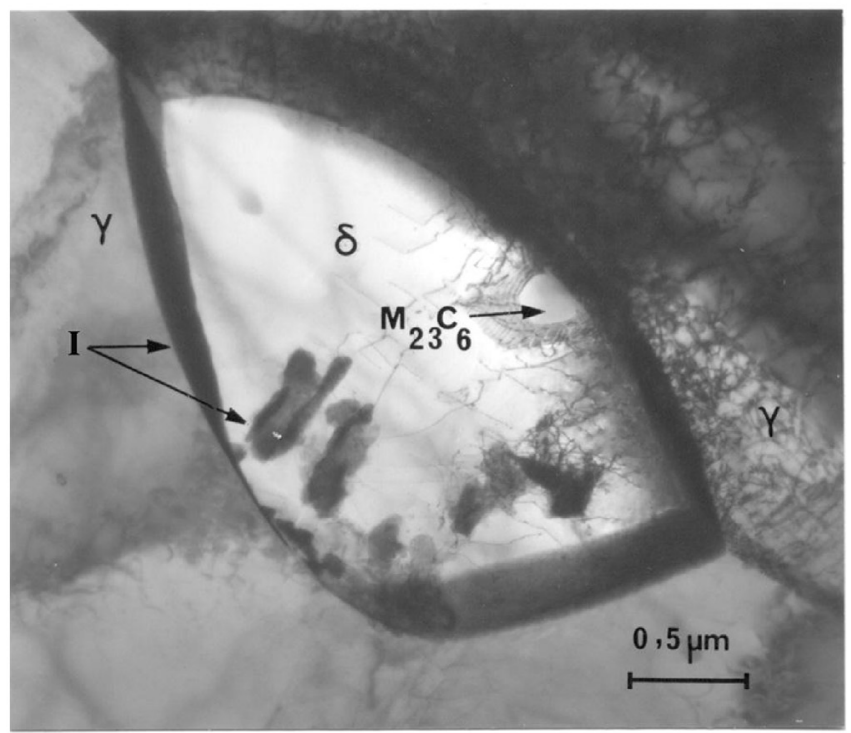

$\mathbf{a}$

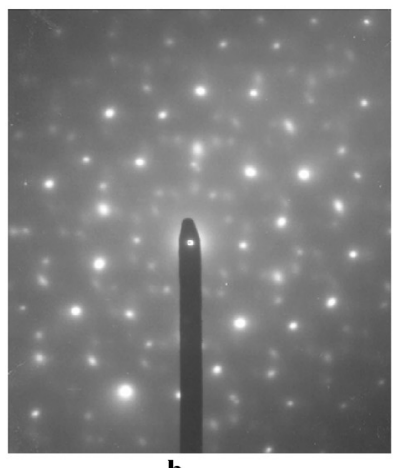

b
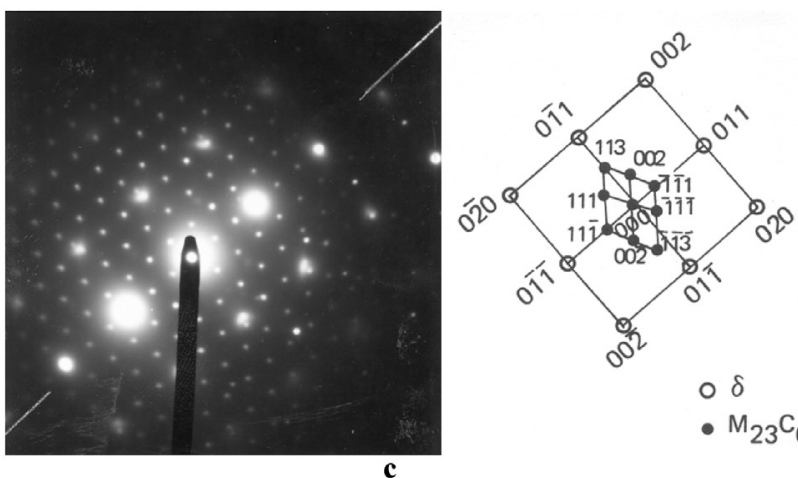

$\circ \delta$

- $\mathrm{M}_{23} \mathrm{C}_{6}$

Fig. 4. Decomposition of $\delta$ ferrite after aging at $550{ }^{\circ} \mathrm{C}$ during $1000 \mathrm{~h}$ (TEM examination): (a) F.K phase (I phase) and $\mathrm{M}_{23} \mathrm{C}_{6}$ carbide at the $\delta / \gamma$ interface; (b) SAD of F.K phase and $\delta$ ferrite matrix; (c) SAD of $\mathrm{M}_{23} \mathrm{C}_{6}$ carbide and $\delta$ ferrite matrix.

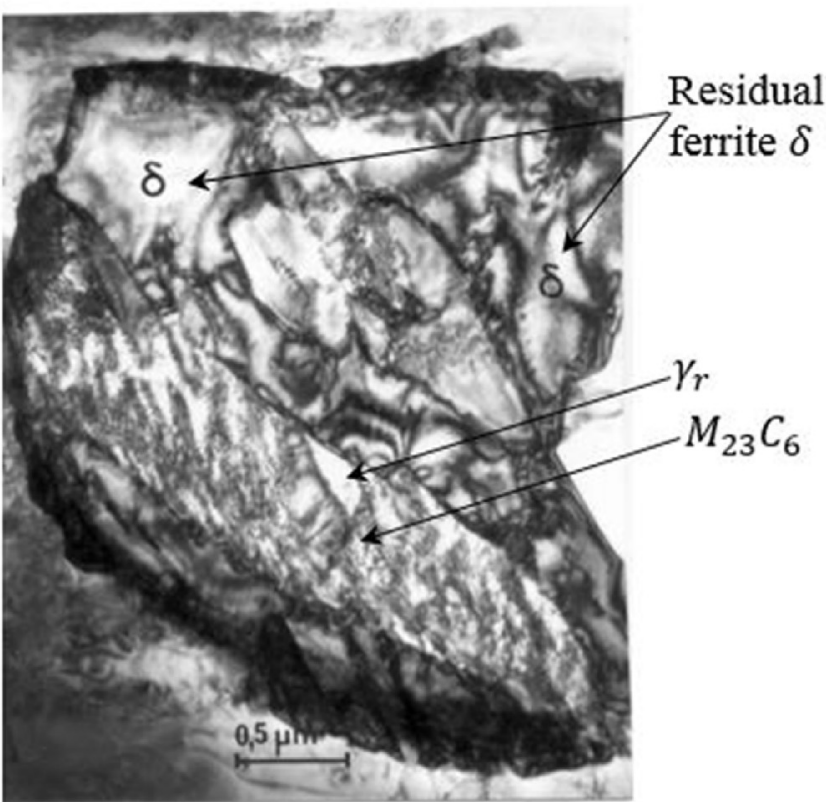

a

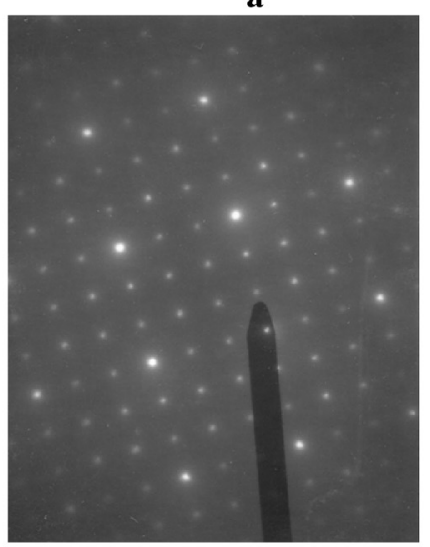

b

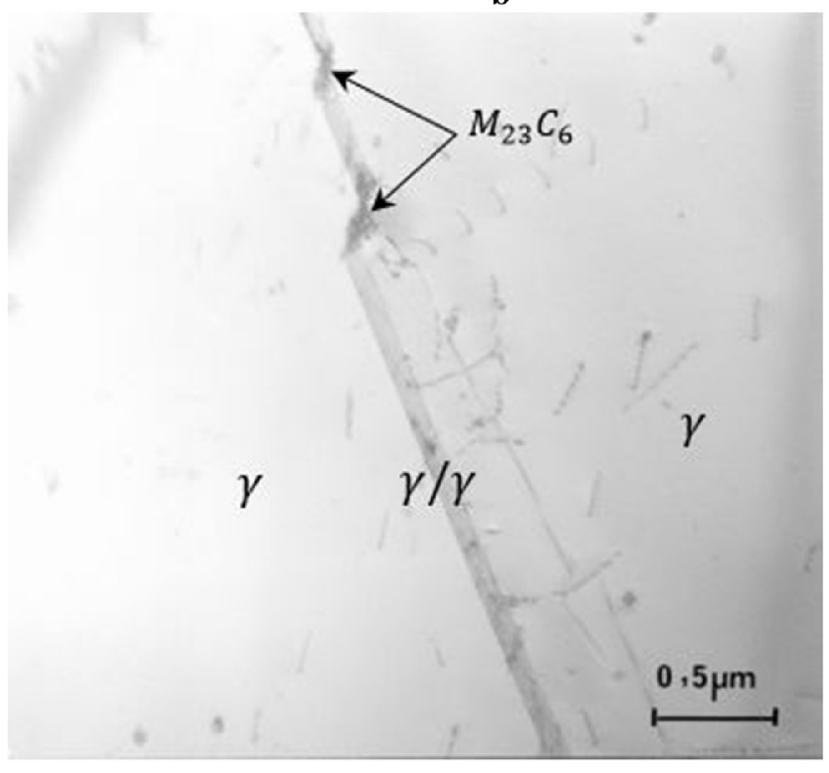

c

Fig. 5. Decomposition of $\delta$ ferrite after aging at $550{ }^{\circ} \mathrm{C}$ during $10000 \mathrm{~h}$ (TEM examination): (a) Decomposition of $\delta$ ferrite into $\mathrm{M}_{23} \mathrm{C}_{6}$ and regenered austenite $\left(\gamma_{\mathrm{r}}\right)$; (b) SAD of $M_{23} C_{6}$ carbide and regenered austenite $\left(\gamma_{r}\right)$; (c) Nucleation of $M_{23} C_{6}$ carbide at the austenite grain boundaries. 


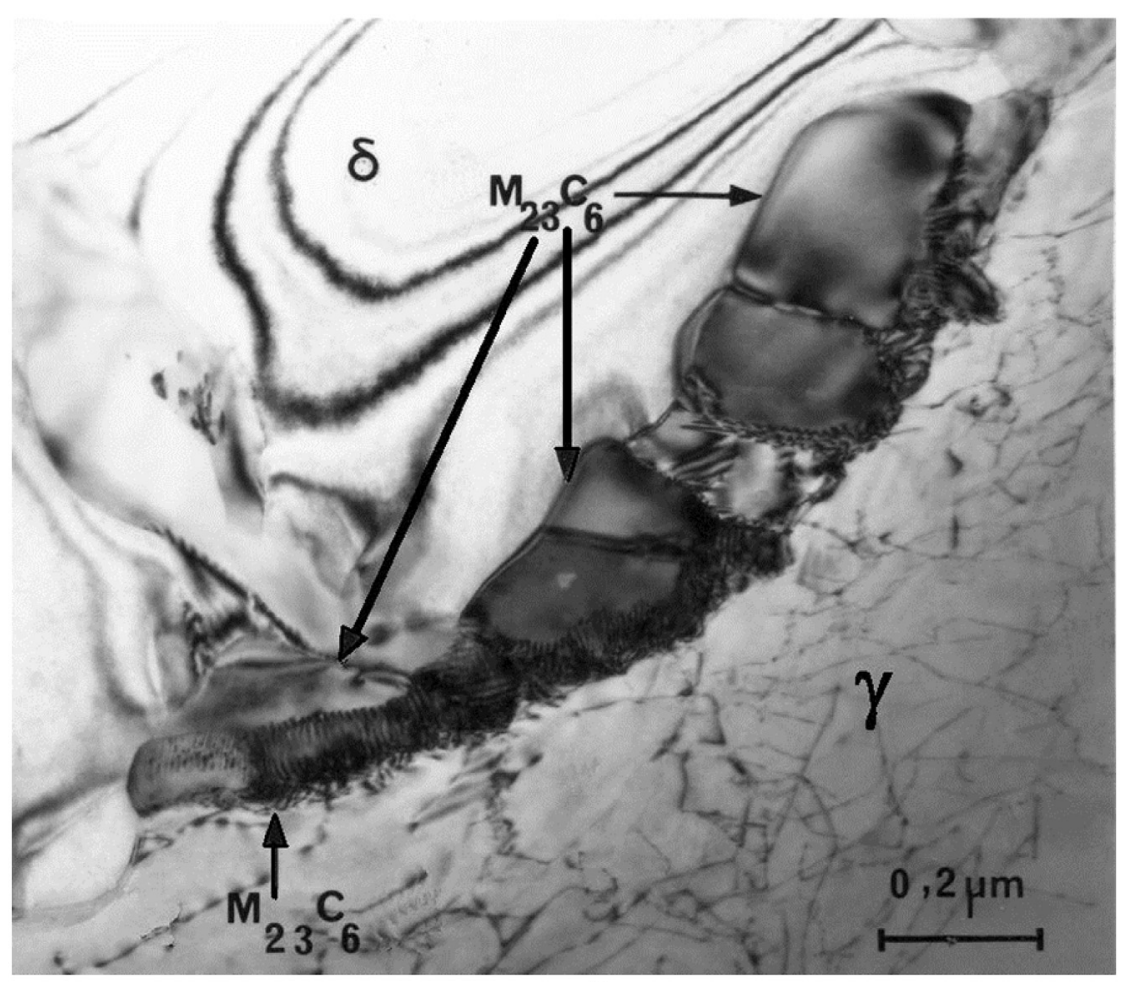

a

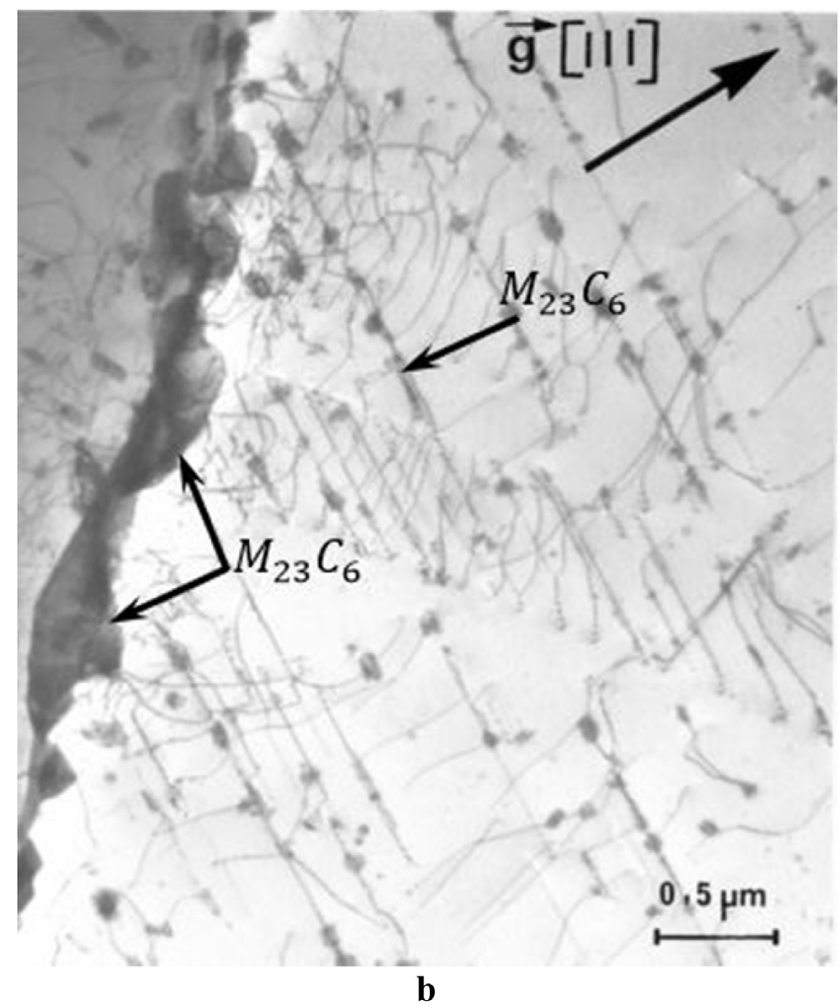

Fig. 6. Nucleation and growth of $\mathrm{M}_{23} \mathrm{C}_{6}$ carbide after aging at $550{ }^{\circ} \mathrm{C}$ during $80000 \mathrm{~h}$ : (a) Coarsing of $\mathrm{M}_{23} \mathrm{C}_{6}$ carbide at $\gamma / \delta$ interface; (b) Nucleation of intragranular $\mathrm{M}_{23} \mathrm{C}_{6}$ on the dislocation pull ups.

interfaces and later at $\gamma / \gamma$ grain boundaries and inside the austenite grains. Therefore, the $\delta$-ferrite domain gradually becomes smaller due to the decomposition process and eventually disappears completely after $10000 \mathrm{~h}$ at $650{ }^{\circ} \mathrm{C}$ to the benefit of intermetallic phases $\sigma, \chi, \eta$ (Laves phase), $R$ and regenerated austenite $\gamma_{\mathrm{r}}$
(Fig. 7a). The SAD related to each phase was reported in Fig. 7 b, c, $\mathrm{d}$ and e. The second austenite phase $\gamma_{\mathrm{r}}$ formed initially at the $\delta / \gamma$ interfaces grew along the austenite phase edge. This phase is therefore not easily distinguishable from the annealed austenite. The $\chi, \eta$ and $R$ phases appeared systematically with the $\sigma$-phase 

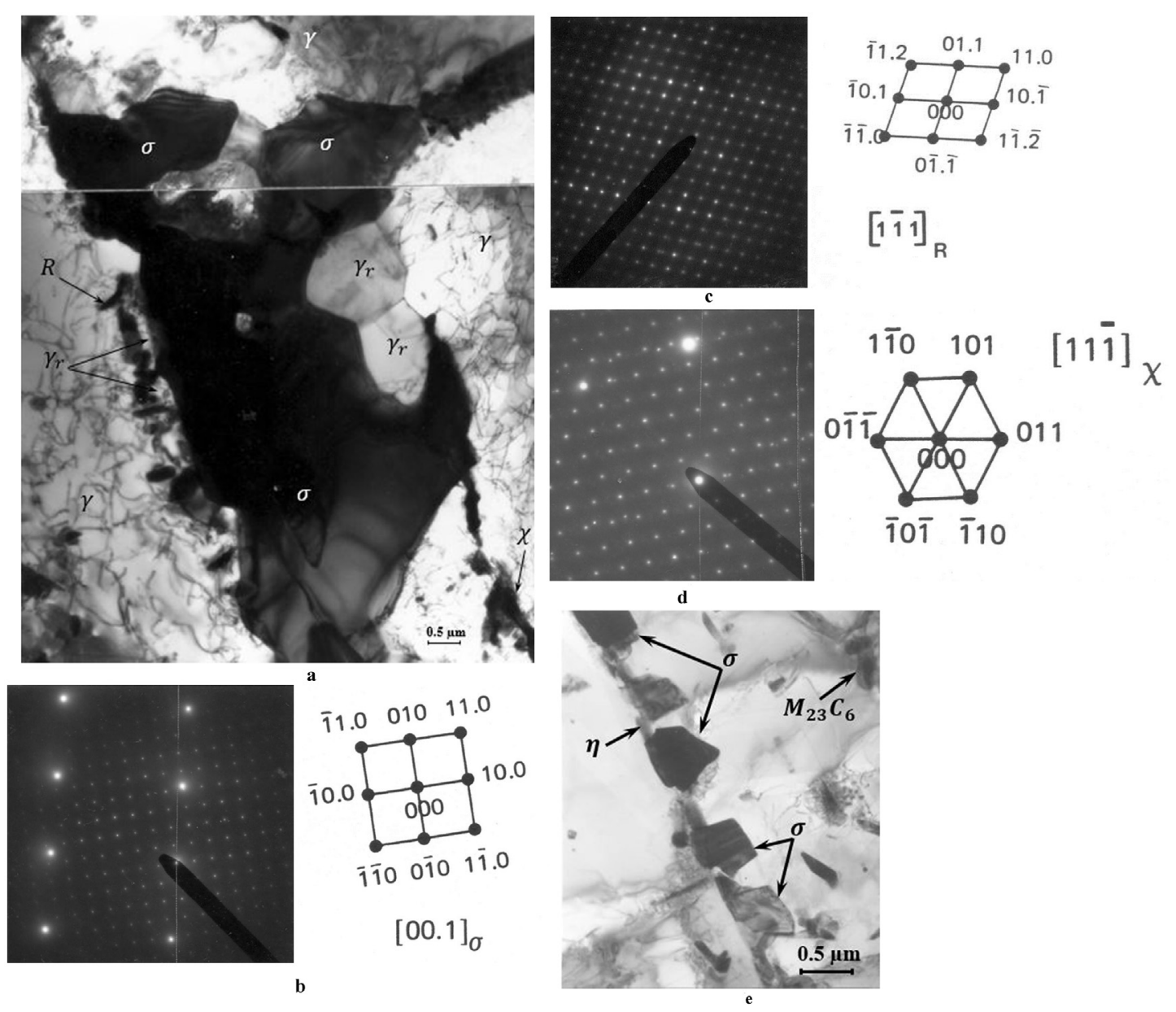

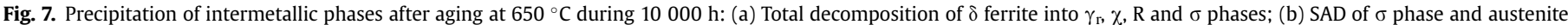
matrix; (c) SAD of R phase; (d) SAD of $\chi$ phase and austenite matrix; (e) Nucleation and growth of $\sigma$ phase at the austenite grain boundaries.

although it seems that they precipitated prior to $\sigma$-phase because of the required higher interface energy. Moreover, $\sigma$-phase was larger than the other intermetallic phases and its volume fraction increased with increasing aging time and temperature. Otherwise, the absence of carbides, as a $\delta$ decomposition product, suggests that

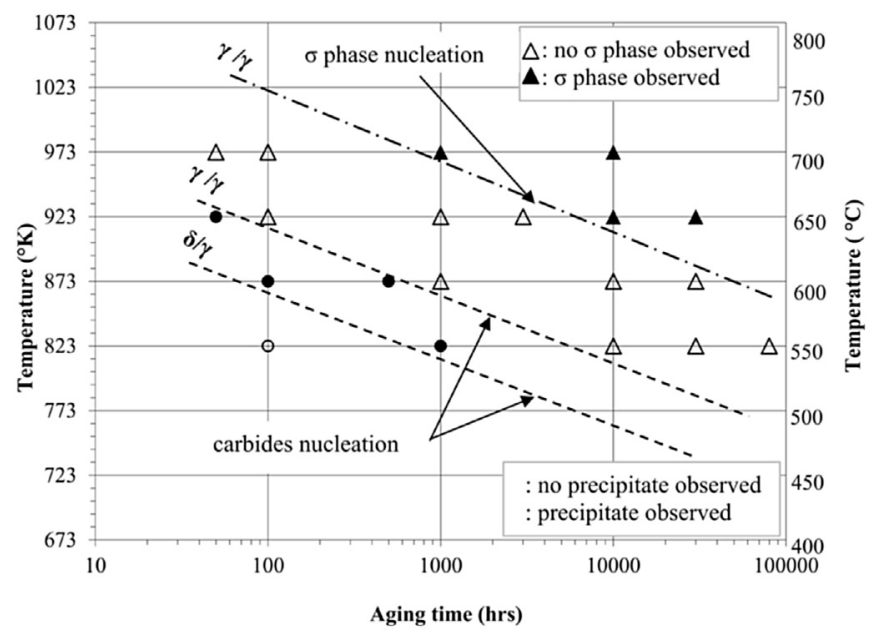

Fig. 8. TTP diagram of AISI $316 \mathrm{~L}$ with low ferrite content using TEM examination results. these carbides are completely dissolved in favor of $\sigma$-phase which evolves substantially into ferrite. Because of the complete decomposition of the $\delta$-phase, there was no significant microstructural changes related to the ferrite islands after extending the aging periods to up to $30000 \mathrm{~h}$ at $650{ }^{\circ} \mathrm{C}$. However, carbides, $\eta$ and $\sigma$ phases nucleated at the $\gamma / \gamma$ grain boundaries grew by increasing aging time (Fig. 7e).

The results of TEM examinations, reported in Table 2, were used to construct the TTP diagram by plotting the time and temperature of the second phase nucleation in each parent phase ( $\delta$ and $\gamma$ ). This diagram showed that the microstructure instability of the annealed AISI $316 \mathrm{~L}$ underwent decomposition during aging at temperatures ranging from 550 to $700{ }^{\circ} \mathrm{C}$ (Fig. 8). According to the experimental results, the transformation mechanisms of the parent phases $\delta$ and $\gamma$ that depend basically on the aging time and temperature could be described as follows:

$$
\begin{aligned}
& \delta \rightarrow\left(\text { F.K) phases }+\mathrm{M}_{23} \mathrm{C}_{6} \rightarrow \mathrm{M}_{23} \mathrm{C}_{6}+\gamma_{\mathrm{r}} \rightarrow \gamma_{\mathrm{r}}+\eta+\chi+\mathrm{R}+\sigma\right. \\
& \gamma \rightarrow \gamma+\mathrm{M}_{23} \mathrm{C}_{6}+\eta+\sigma
\end{aligned}
$$

\subsubsection{Chromium-rich phases}

Precipitates identification was completed by quantitative analysis of their chemical composition which is carried out on an extractive replica in STEM. Results reported in Table 3 confirm that carbides were chromium rich phase (71 wt \%). The intermetallic 
Table 3

Chemical composition of carbide and intermetallic phases formed during aging of AISI 316L (EDS analysis in STEM).

\begin{tabular}{|c|c|c|c|c|c|c|c|c|}
\hline \multicolumn{2}{|l|}{ Aging conditions } & \multirow[t]{2}{*}{ Phases } & \multicolumn{6}{|c|}{ Elements content (wt. \%) } \\
\hline Temperature $\left({ }^{\circ} \mathrm{C}\right)$ & Duration (h) & & $\mathrm{Si}$ & $\mathrm{Cr}$ & Mn & $\mathrm{Fe}$ & $\mathrm{Ni}$ & Mo \\
\hline 550 & 100 & F.K phase & 3.0 & 30.0 & 1.3 & 28.3 & 4.1 & 33.3 \\
\hline 550 & 80000 & $\mathrm{M}_{23} \mathrm{C}_{6}$ & 0.2 & 71.2 & 1.6 & 16.8 & 2.4 & 7.8 \\
\hline 650 & 10000 & Laves phase $\eta$ & 3.5 & 33.0 & 1.4 & 27.6 & 4.5 & 30.0 \\
\hline 650 & 10000 & $\chi$ & 1.4 & 25.0 & 2.5 & 50.0 & 3.0 & 18.1 \\
\hline 650 & 10000 & $\mathrm{R}$ & 1.5 & 20.0 & 1.0 & 47.3 & 3.5 & 27 \\
\hline 650 & 10000 & $\sigma$ & 0.8 & 35.8 & 2 & 50 & 2.7 & 8.7 \\
\hline 650 & 10000 & $\gamma_{\mathrm{r}}$ & 0.3 & 16 & 1.6 & 74.1 & 7.2 & 0,8 \\
\hline
\end{tabular}

compounds such as F.K, $\eta, \chi, \mathrm{R}$ and $\sigma$ were chromium and molybdenum rich phases. These results also show that the chromium content of the secondary austenite $\left(\gamma_{\mathrm{r}}\right)(14-16 \mathrm{wt} \%)$ resulting from the $\delta$-ferrite decomposition, is slightly lower than that of the initial austenite (17.4 wt \%). The chromium enrichment of the precipitates results in the depletion of the neighboring regions, as illustrated qualitatively by chromium mapping provided by STEM X-ray image using chromium $\mathrm{K} \alpha$ radiation (Fig. 9). Mapping showing brightness contrast is related to different $\mathrm{Cr}$-enrichment. The brightest zone corresponds to $\mathrm{Cr}$-enriched $\mathrm{M}_{23} \mathrm{C}_{6}$ carbide formed during aging at the $\delta / \gamma$ interfaces (Fig. 9a) and at the $\gamma / \gamma$ grain boundaries (Fig. 9b). It is also shown that the carbide chromium enrichment was made at the expense of the surrounding ferrite and austenite grain boundary regions.

\subsubsection{Chromium depleted area}

As shown in Fig. 9, the nucleation and growth of chromium-rich phases and mainly $\mathrm{M}_{23} \mathrm{C}_{6}$ carbides, impact chromium content and increase the chromium depleted zones in the vicinity of the $\gamma / \gamma$ grain boundaries, the $\delta / \gamma$ interfaces and inside the remained $\delta$ ferrite. The chromium profiles, established by EDX microanalysis in STEM, provide quantitative evolution of the chromium concentration and the extent of the depleted zones which are related to the intergranular $(\gamma / \gamma)$ precipitation of chromium-rich phases which depends mainly on the aging duration and temperature (Fig. 10). It can be inferred that chromium level at the $\gamma / \gamma$ grain boundaries (and also at the $\gamma / \mathrm{M}_{23} \mathrm{C}_{6}$ interphase) falls below $12 \mathrm{wt} \%$ (13 at \%) during aging at $550{ }^{\circ} \mathrm{C}$ for durations between $10000 \mathrm{~h}$ and $80000 \mathrm{~h}$ and that the chromium depleted area width increased from $40 \mathrm{~nm}$ to $200 \mathrm{~nm}$ (Fig. 10a). During aging at $600{ }^{\circ} \mathrm{C}$, the chromium content at the $\gamma / \gamma$ grain boundaries falls below $12 \%$ wt after a period of $1000 \mathrm{~h}$ and recovers gradually its initial level after a duration higher than $30000 \mathrm{~h}$ (Fig. 10b). At a temperature of $650{ }^{\circ} \mathrm{C}$, the rechromisation phenomenon was fast enough for the $\gamma / \gamma$ chromium level (16.5 wt \%) to almost fully recover when the aging time reaches $10000 \mathrm{~h}$ (Fig. 10c).

Similarly, the $\delta$-ferrite chromium concentration decreased significantly during aging as a consequence of carbides and intermetallic phase precipitation (Fig. 11). The minimum chromium content ranging from $8 \mathrm{wt} \%$ to $10 \mathrm{wt} \%$ was reached at $550{ }^{\circ} \mathrm{C}$ for aging durations ranging from $10000 \mathrm{~h}$ to $80000 \mathrm{~h}$. At higher temperatures, chromium decreased rapidly below $8 \mathrm{wt} \%$ before complete decomposition of $\delta$-ferrite which occurred after $30000 \mathrm{~h}$ at $600{ }^{\circ} \mathrm{C}, 10000 \mathrm{~h}$ at $650{ }^{\circ} \mathrm{C}$ and only $100 \mathrm{~h}$ at $700{ }^{\circ} \mathrm{C}$. Therefore 14 to $16 \mathrm{wt} \%$ chromium content was measured in secondary austenite $\left(\gamma_{\mathrm{r}}\right)$.

\subsection{Intergranular corrosion behavior}

\subsubsection{Time-temperature-sensitization diagram}

The experimental values of the ratio $\mathrm{Ir} / \mathrm{Ia}(\%)$, resulting from the DL-EPR tests conducted on the annealed and aged specimens are listed in Table 4. Ir/Ia, considered as an indicator of the DOS, evolved from $0 \%$ (unsensitized state) to $38.4 \%$ (very sensitized state). The sensitization at $550{ }^{\circ} \mathrm{C}$ occurred after $10000 \mathrm{~h}$ and continued beyond $80000 \mathrm{~h}$. At higher temperatures, the sensitization is rapid and followed by the desensitization, which is marked by the drop of the $\mathrm{Ir} / \mathrm{Ia}$ ratio to $0 \%$. This desensitization occurs after aging for
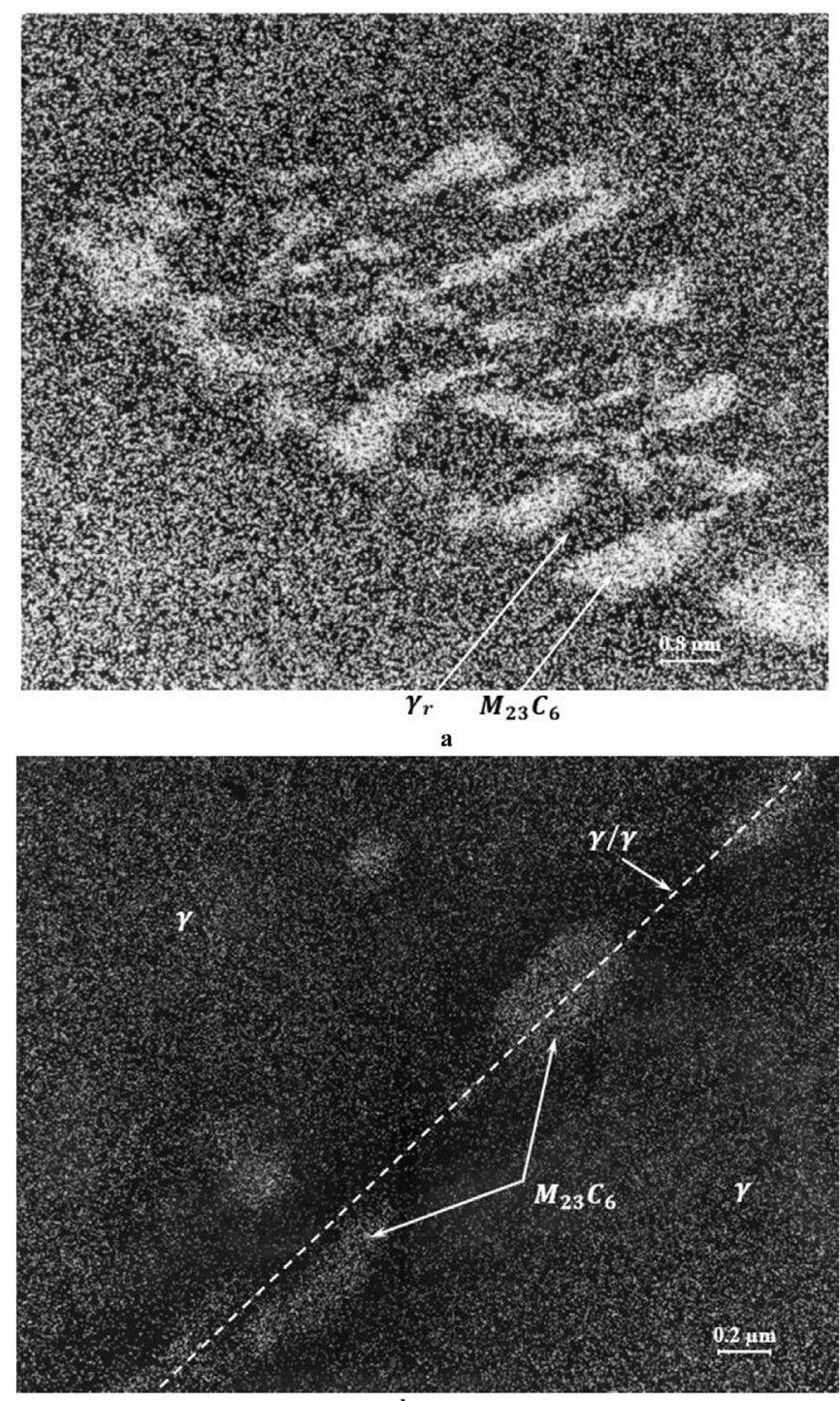

Fig. 9. Chromium depleted area resulting from nucleation and growth of $\mathrm{M}_{23} \mathrm{C}_{6}$ richchromium carbide after aging at $600{ }^{\circ} \mathrm{C}$ during $10000 \mathrm{~h}$ (STEM micrographs); (a) $\mathrm{K} \alpha$ chromium mapping into $\delta$ ferrite; (b) $\mathrm{K} \alpha$ chromium mapping of austenite grain boundarie region. 

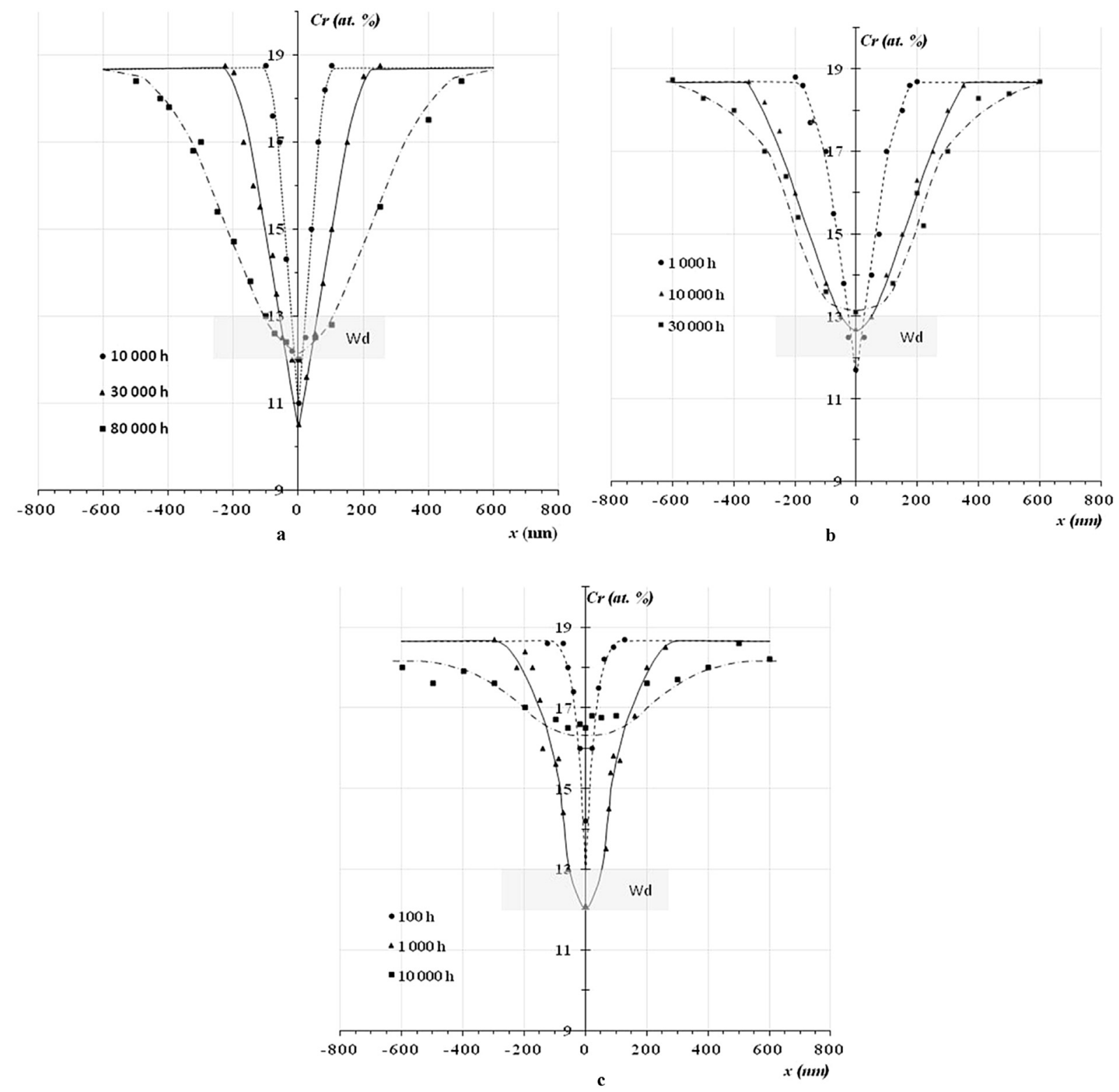

Fig. 10. Evolution of chromium concentration at the vicinity of austenitic grain boundary during aging of AISI $316 \mathrm{~L} ;(\mathrm{a}) \mathrm{T}=550{ }^{\circ} \mathrm{C} ;(\mathrm{b}) \mathrm{T}=600{ }^{\circ} \mathrm{C} ;(\mathrm{c}) \mathrm{T}=650{ }^{\circ} \mathrm{C}$.

periods longer than $30000 \mathrm{~h}$ at $600{ }^{\circ} \mathrm{C}, 10000 \mathrm{~h}$ at $650{ }^{\circ} \mathrm{C}$ and $1000 \mathrm{~h}$ at $700^{\circ} \mathrm{C}$. Using the sensitization criteria Ir/Ia $\geq 1 \%$, the TTS diagram was established (Fig. 12 a). It can be inferred that aging at temperatures ranging from 550 to $700{ }^{\circ} \mathrm{C}$ sensitized the low ferrite content austenitic stainless steel to IGC. At the peak temperature which is around $730^{\circ} \mathrm{C}$, the time required for sensitization is about $50 \mathrm{~h}$ while it is higher than $8000 \mathrm{~h}$ at $550{ }^{\circ} \mathrm{C}$. The sensitization period $\left(\Delta t=t_{f}-t_{s}\right)$ defined as the difference between the sensitization finishing time $\left(t_{f}\right)$ and the sensitization starting time $\left(t_{s}\right)$ varies between $650 \mathrm{~h}$ at $700{ }^{\circ} \mathrm{C}$ and $200000 \mathrm{~h}$ at $550{ }^{\circ} \mathrm{C}$. It is important to notice that, in industrial practice, the TTS diagram can be directly used for controlling the risk of IGC sensitization under isothermal heating. In order to avoid the sensitization resulting from continuous cooling through the sensitization temperature range, the cooling rate must be above a critical value. This value is different from that provided by the intersection of superimposed cooling curve and the isothermal TTS diagram as
$\frac{\Delta T_{500}^{700}}{\Delta t_{500}^{700}}=220^{ \pm 20}{ }^{\circ} \mathrm{C} / \mathrm{h}$. This difference is the result of not taking into account the effect of time spent at the different temperature levels during cooling. Therefore, Dayal et al. [13] proposed a new method to calculate, from TTS diagram, the CCR which is of great interest to predict whether the cooling of heated or welded structure was sensitized or not. According to Dayal et al., the CCR is given by equation (1):

$C C R=\Delta T \sum_{T_{L}}^{T_{H}} \frac{1}{t_{S}}$

Where $T_{H}$ is the highest temperature, $T_{L}$ is the lowest temperature, ts is the sensitization time and $\Delta T$ is the temperature difference in the considered small temperature steps.

The calculated CCR value is $24 \mathrm{~K} / \mathrm{h}$ for AISI $316 \mathrm{~L}$ with $1 \% \delta$-ferrite. Otherwise, from the superimposition of TTP and TTS diagrams in 


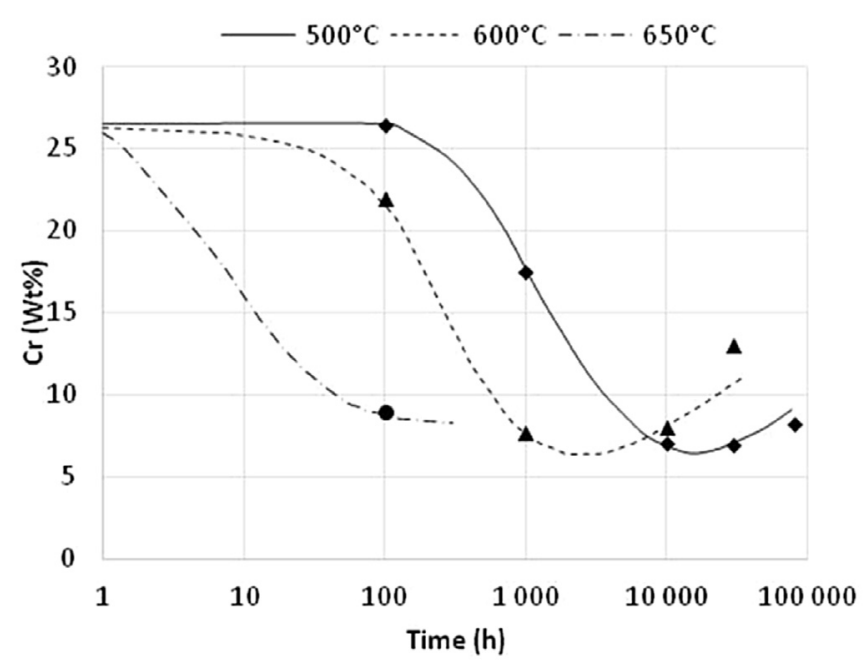

Fig. 11. Evolution $\delta$ ferrite chromium content during aging of AISI $316 \mathrm{~L}$.

selected 1/T (K)-Ln (t) axis (Fig. 12 b) it can be seen that:

- The IGC sensitization is considered to be the consequence of $\mathrm{M}_{23} \mathrm{C}_{6}$ carbide nucleation and growth, while it seems to be independent of $\sigma$-phase precipitation which occurs at higher temperature and longer aging duration corresponding to desensitization region;

- The chromium-rich carbide precipitation and subsequent sensitization and desensitization phenomena are thermally activated processes. Assuming that the processes follow an Arrhenuis rate equation, the time to IGC sensitization can be written as follows:

$t=C \cdot \exp \left(-\frac{Q}{R T}\right)$

Where $\mathrm{C}$ is a constant, $R=8.314 \mathrm{~J} \cdot \mathrm{mol}^{-1} \cdot \mathrm{K}^{-1}, \mathrm{Q}\left(\mathrm{J} \cdot \mathrm{mol}^{-1}\right)$ is the activation energy and $\mathrm{T}$ is the absolute temperature in Kelvin.

The activation energy which is valid at temperatures ranging between $550{ }^{\circ} \mathrm{C}$ and $700{ }^{\circ} \mathrm{C}$ was assessed to be $260 \pm 14 \mathrm{KJ}$.mole ${ }^{-1}$ corresponding to the Chromium diffusion process in austenitic steels as reported in the literature [14]. Therefore, an equivalent time-temperature relationship can be used to predict the duration of equivalent DOS resulting from other aging temperatures, using the following equation:

$\frac{t 1}{t 2}=\exp \left(-\frac{Q}{R}\left(\frac{1}{T 1}-\frac{1}{T 2}\right)\right)$

Where $t_{1}$ is aging duration at temperature $T_{1}, t_{2}$ is aging duration at temperature $T_{2}, \mathrm{R}$ is ideal gas constant and $\mathrm{Q}$ is apparent activation energy.

Using this equation, it is easy to verify that the DOS of samples aged for $10000 \mathrm{~h}$ at $550{ }^{\circ} \mathrm{C}$ is similar to that of samples aged for $1000 \mathrm{~h}$ at $600^{\circ} \mathrm{C}$.

\subsubsection{Intergranular corrosion morphologies}

The IGC morphologies observed after etching according to the ASTM A262 practice A standard, for various aging conditions revealed globally an attacked structure "closely" correlated with the DOS determined by the Ir/la ratio. It is clear that the higher the DOS the wider the corrosion attack at the $\gamma / \gamma$ grain boundaries, which indicates a selective dissolution of chromium depleted area (Fig. 13). As expected, the annealed specimen which is declared unsensitized by the DL-EPR test (DOS $=0 \%$ ) did not show any IGC attack and consequently, it is classified as "step structure", according to the ASTM A262 practice A standard [38] (Fig. 13a, d and 13g). However, the specimens aged at $550{ }^{\circ} \mathrm{C}$ showed evident attack at the $\gamma / \gamma$ grain boundaries, a slight attack at the $\delta / \gamma$ interface and a local attack inside $\delta$. These attacks increased with increasing aging time as evidenced by the DOS evolving from $2.5 \%$ for a $10000 \mathrm{~h}$ aging period (Fig. 13b) to $38.4 \%$ for an $80000 \mathrm{~h}$ aging period (Fig. 13c). For $10000 \mathrm{~h}$ aging period, attack structure were classified as "dual structure", meanwhile for $80000 \mathrm{~h}$ aging period the attack structure was considered as "ditch structure" since numerous grains were completely encircled by attack. Similar morphologies (dual) were observed at higher temperatures but for shorter aging periods such as $1000 \mathrm{~h}$ at $600{ }^{\circ} \mathrm{C}$ (Fig. 13e) and $100 \mathrm{~h}$ at $650{ }^{\circ} \mathrm{C}$ (Fig. 13h). Longer periods at these temperatures showed ditch structure (Fig. 13f and i). Based on the above observations, the DL-EPR test results are correlated with the results of tests conducted according to the ASTM A262 practice A and therefore, the criterion of sensitization starting $\mathrm{Ir} / \mathrm{Ia} \geq 1 \%$ is realistic since it is well validated by the IGC morphologies shown in Fig. 13. It is important to notice

Table 4

DOS values resulting from DL-EPR tests carried out on the aged AISI 316L specimens.

\begin{tabular}{|c|c|c|c|c|c|c|c|}
\hline \multicolumn{2}{|l|}{ Aging conditions } & \multicolumn{6}{|c|}{ Degree of sensitization } \\
\hline Temperature $\left({ }^{\circ} \mathrm{C}\right)$ & Duration $(\mathrm{h})$ & $\mathrm{I}_{\mathrm{a}}\left(\mathrm{mA} / \mathrm{cm}^{2}\right)$ & $\mathrm{I}_{\mathrm{r}}\left(\mathrm{mA} / \mathrm{cm}^{2}\right)$ & $\mathrm{I}_{\mathrm{r}} / \mathrm{I}_{\mathrm{a}}(\%)$ & $\mathrm{Q}_{\mathrm{a}}\left(\mu \mathrm{C} / \mathrm{cm}^{2}\right)$ & $\mathrm{Q}_{\mathrm{r}}\left(\mu \mathrm{C} / \mathrm{cm}^{2}\right)$ & $\mathrm{Q}_{\mathrm{r}} / \mathrm{Q}_{\mathrm{a}}(\%)$ \\
\hline 1100 & 1 & 1.79 & 0.0 & 0.0 & 107.66 & 0.0 & 0.0 \\
\hline \multirow[t]{4}{*}{550} & 1000 & 2.29 & 0.0 & 0.0 & 150.15 & 0.0 & 0.0 \\
\hline & 10000 & 5.25 & 0.13 & 2.5 & 429.22 & 39.15 & 9.1 \\
\hline & 30000 & 11.06 & 0.8 & 7.2 & 1054.6 & 178.3 & 16.9 \\
\hline & 80000 & 11.16 & 4.28 & 38.4 & 1093.8 & 550.5 & 50.3 \\
\hline \multirow[t]{4}{*}{600} & 500 & 2.14 & 0.0 & 0.0 & 135.12 & 0.0 & 0.0 \\
\hline & 1000 & 9.24 & 0.23 & 2.5 & 752.18 & 27.48 & 3.7 \\
\hline & 10000 & 9.45 & 1.64 & 17.4 & 781.24 & 167.2 & 21.4 \\
\hline & 30000 & 20.13 & 0.51 & 2.5 & 1990.5 & 50.44 & 2.5 \\
\hline \multirow[t]{5}{*}{650} & 50 & 2.05 & 0.0 & 0.0 & 131.12 & 0.0 & 0.0 \\
\hline & 100 & 8.83 & 0.24 & 2.8 & 736.76 & 26.22 & 3.6 \\
\hline & 1000 & 9.87 & 3.29 & 33.3 & 910.27 & 291.5 & 32.0 \\
\hline & 10000 & 26.15 & 0.0 & 0.0 & 2369.2 & 0.0 & 0.0 \\
\hline & 30000 & 40.04 & 0.0 & 0.0 & 3832.0 & 0.0 & 0.0 \\
\hline \multirow[t]{4}{*}{700} & 50 & 3.35 & 0.20 & 2.6 & 1391.9 & 43.15 & 3.1 \\
\hline & 100 & 4.54 & 0.77 & 17.0 & 375.75 & 81.89 & 21.79 \\
\hline & 1000 & 15.43 & 0.0 & 0.0 & 1357.7 & 0.0 & 0.0 \\
\hline & 10000 & 29.62 & 0.0 & 0.0 & 2604.7 & 0.0 & 0.0 \\
\hline
\end{tabular}


that the attack on the $\delta / \gamma$ interface was rarely observed, even after a total decomposition of $\delta$-ferrite into $\sigma$-phase. This suggests that there is no detrimental effect of the $1 \%$ wt of the $\delta$ ferrite on the IGC resistance of austenitic stainless steel. However some pits resulting from $\delta$-ferrite decomposition were observed in the vicinity of $\sigma$-phase (Fig. 14).

\subsection{Microstructure-intergranular corrosion sensitization/ desensitization relationship}

The correlation between microstructure and DL-EPR results completed by the IGC morphologies is evidenced by data reported in Table 5. It gives a great importance to chromium-depleted areas

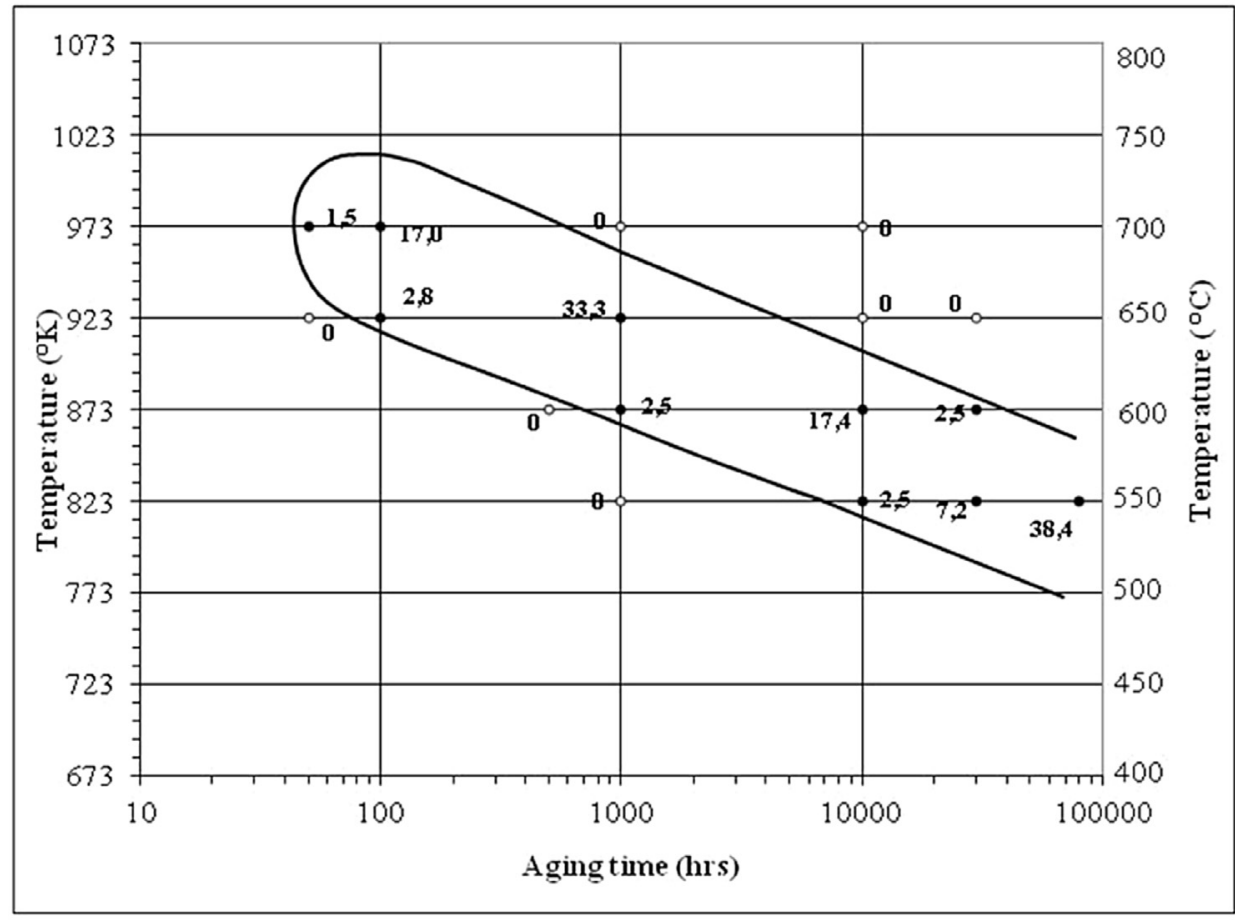

a

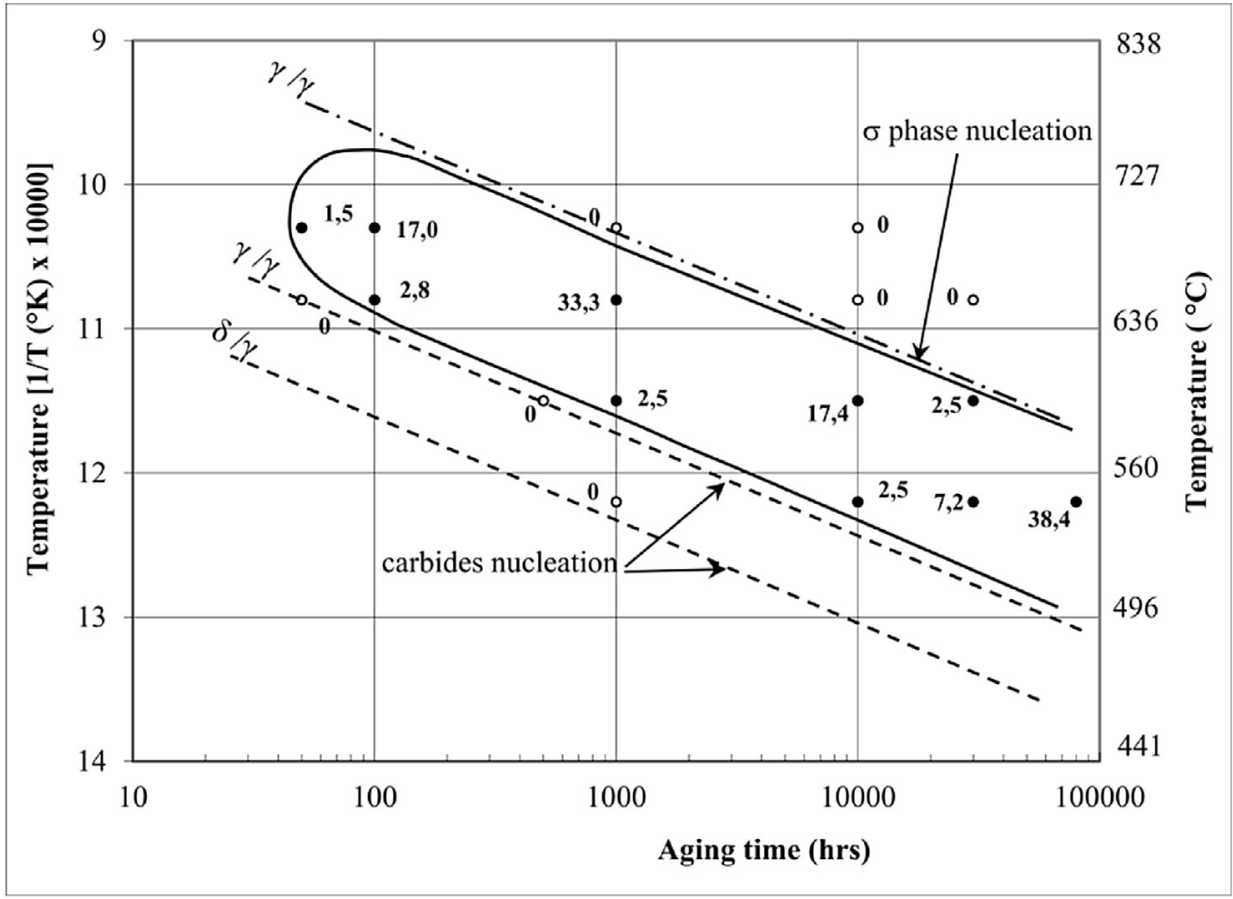

b

Fig. 12. Effect of rich-chromium phase on the IGC sensitization of AISI 316 L; (a) TTS diagram using the DOS resulting from DL-EPR tests; (b) Correlation between TTP and TTS. 

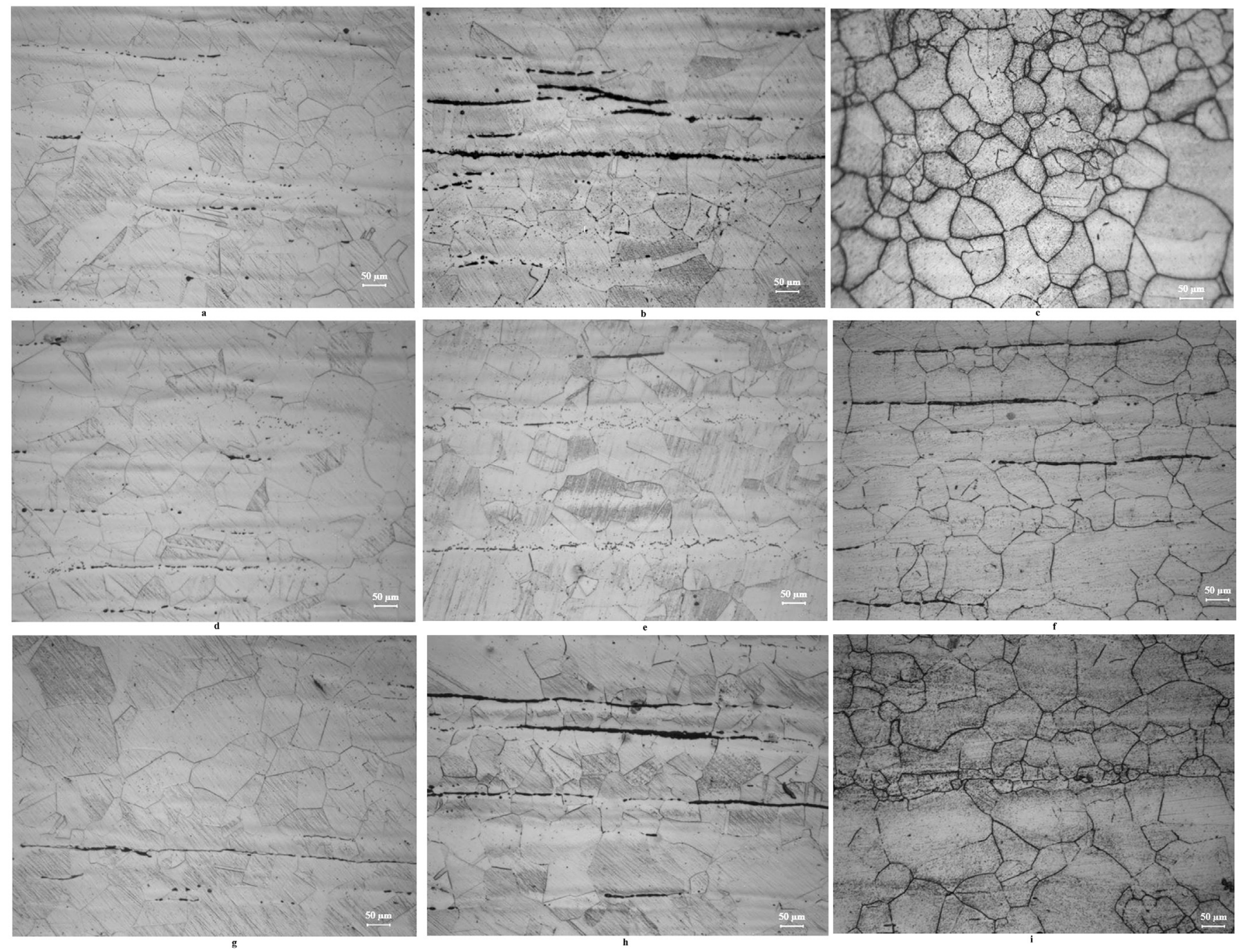

Fig. 13. ICG morphologies observed after the DL-EPR test (Optical micrographs); (a) $550{ }^{\circ} \mathrm{C}-1000 \mathrm{~h}$, DOS $=0 \%$, step; (b) $550{ }^{\circ} \mathrm{C}-10000 \mathrm{~h}, \mathrm{DOS}=2.5 \%$, dual; (c) $550{ }^{\circ} \mathrm{C}-80000 \mathrm{~h}$, DOS $=38.4 \%$, ditch; (d) $600{ }^{\circ} \mathrm{C}-500 \mathrm{~h}, \mathrm{DOS}=0 \%$, step; (e) $600{ }^{\circ} \mathrm{C}-1000 \mathrm{~h}, \mathrm{DOS}=2.5 \%$, dual; (f) $600{ }^{\circ} \mathrm{C}-10000 \mathrm{~h}, \mathrm{DOS}=17.4 \%$, ditch, (g) $650{ }^{\circ} \mathrm{C}-50 \mathrm{~h}, \mathrm{DOS}=0 \%$, step; (h) $650{ }^{\circ} \mathrm{C}-$ $100 \mathrm{~h}, \mathrm{DOS}=2.8 \%$, dual; (i) $650{ }^{\circ} \mathrm{C}-1000 \mathrm{~h}$, DOS $=33,3 \%$, ditch.

which are characteristics of the corrosion behavior of low ferrite content AISI 316L stainless steel. It appears that aging at temperatures ranging from 550 to $700{ }^{\circ} \mathrm{C}$ for exposure periods varying between $100 \mathrm{~h}$ and $80000 \mathrm{~h}$ generated various chromium-rich phases and mainly $\mathrm{M}_{23} \mathrm{C}_{6}$ which are responsible for chromium depletion in the vicinity of austenite grain boundaries and inside the ferrite islands. The nucleation and growth of carbides during aging modify significantly the size and the chromium concentration $(\% \mathrm{Cr}$ ) of the depleted areas as shown in column 3, 4 and 5 of Table 5. Columns 6 and 7 showed that the IGC sensitization corresponding to DOS $\geq 1 \%$ results in predominant intergranular attacks (ditch structure) occurring in the chromium-reduced areas with a concentration below the critical value of $(\% \mathrm{Cr})_{\min } \leq 12-13 \%$ wt and with a width more than $100 \mathrm{~nm}$. Nevertheless, the desensitization, (self-healing) corresponding to a step structure, was achieved when the critical value of the chromium was recovered. The aged $\delta$-ferrite islands are not significantly attacked since their chromium content remained above the critical value (12-13\%wt) during aging for short periods such as $1000 \mathrm{~h}$ at $550{ }^{\circ} \mathrm{C}$, less than $100 \mathrm{~h}$ at $600{ }^{\circ} \mathrm{C}$ and $10 \mathrm{~h}$ at $650{ }^{\circ} \mathrm{C}$. This concentration became higher ( $\geq 14 \% \mathrm{wt}$ ) after the total decomposition into chromium-rich secondary austenite $\left(\gamma_{\mathrm{r}}\right)$ and $\sigma$-phase which occurred for the long durations such as $30000 \mathrm{~h}$ at $600{ }^{\circ} \mathrm{C}$, more than $1000 \mathrm{~h}$ at $650{ }^{\circ} \mathrm{C}$ and $100 \mathrm{~h}$ at $700{ }^{\circ} \mathrm{C}$.

\section{Discussion}

The weldability improvement of austenitic stainless steels requires a small fraction of $\delta$-ferrite that could be achieved by rebalancing the austenitic stainless steel's chemical composition combined with annealing treatment conditions. Therefore, by controlling the equivalent chromium ( $\mathrm{Creq}=23.48 \mathrm{wt} \%$ ) and the equivalent nickel $(\mathrm{Nieq}=14.33 \mathrm{wt} \%$ ) contents, the annealed AISI $316 \mathrm{~L}$ structure consists of a small fraction of $\delta$-ferrite dispersed in an austenite matrix. The subsequent thermo-mechanical treatments formed aligned islands of ferrite in the sheet's rolling direction. The Feritoscope FMP30 measurements provide a fraction of $\delta$-ferrite of about $1 \%$ which is in agreement with values deduced from the Price \& Andrews diagram [50].

Microstructural investigations, conducted in this study, confirmed the well-known instability of both $\gamma$-austenite and $\delta$ ferrite components of the annealed structure during aging at temperatures ranging from 550 to $700{ }^{\circ} \mathrm{C}[27,46]$. Moreover, the fast decomposition of $\delta$-ferrite during aging is expected in accordance 


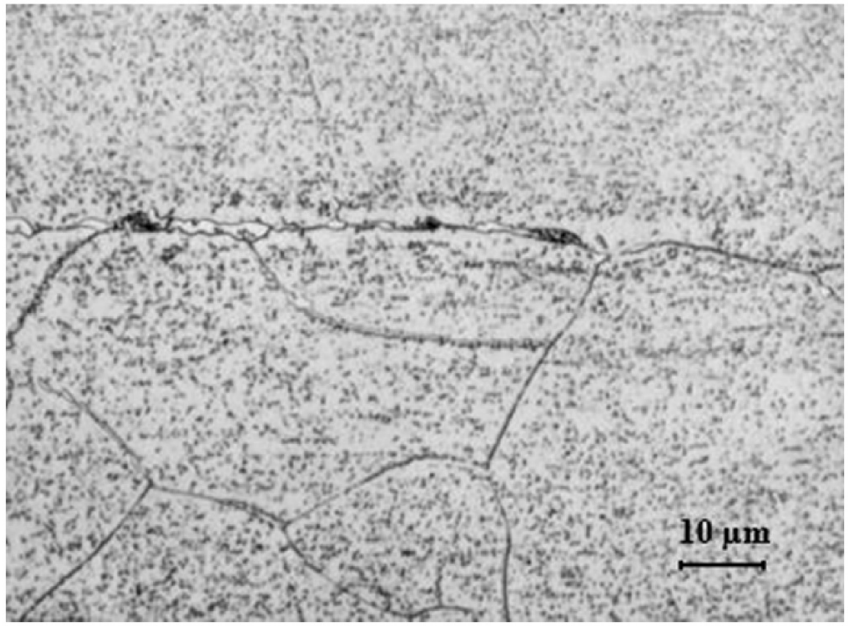

Fig. 14. Pits resulting from $\delta$-ferrite decomposition observed in the vicinity of $\sigma$-phase after aging at $650{ }^{\circ} \mathrm{C}$ during $10000 \mathrm{~h}$.

with the literature results that attributed this phenomenon to the high chromium (27 wt \%) and molybdenum (4 wt\%) contents, compared to those of austenite which are equal to $17.3 \mathrm{wt} \%$ and $2.6 \mathrm{wt} \%$ respectively. Furthermore, the fast chromium diffusion in bcc structure of $\delta$-ferrite comparatively to fcc structure of $\gamma$ austenite as reported in the literature [14] supports the TTP diagram results shown in Fig. 8, indicating the beginning of the chromium carbide precipitation at $\delta / \gamma$ interfaces during aging at temperature ranging from 550 to $700{ }^{\circ} \mathrm{C}$. Therefore, the $\delta$-ferrite decomposed gradually into chromium-rich $\mathrm{M}_{23} \mathrm{C}_{6}$ carbide and into chromium-rich and molybdenum intermetallic phases such as F.K, $\eta, \sigma, \chi$ and $R$. The ultimate stage of decomposition to $\sigma$-phase and regenerated austenite $\gamma_{\mathrm{r}}$ was achieved during aging at $650{ }^{\circ} \mathrm{C}$ and at $700{ }^{\circ} \mathrm{C}$ as shown in Fig. 7. These findings are complemented by the quantitative data reported in Table 2 . The decomposition products of the $\delta$-ferrite during aging have been reported in previous studies related to austenitic stainless steels with low ferrite content $[27,31,34,46,51]$ and to duplex stainless steels [42,52]. This decomposition depends mainly on the chemical composition of the material and on aging temperature. In this study, it has been shown that the precipitation of staking faulted FK phase at the $\delta / \gamma$ interfaces was prior to that of $\mathrm{M}_{23} \mathrm{C}_{6}$ carbide due to the high concentration of chromium and molybdenum in $\delta$-ferrite. By prolonging the aging period, the FK phase growth reduces the ferrite domain and consequently increases the carbon activity in the $\delta$ ferrite that enhances the $\mathrm{M}_{23} \mathrm{C}_{6}$ carbide nucleation as shown in Fig. 4. In its turn, the growth of carbide consumes more chromium and molybdenum that favors the dissolution of metastable FK phase in benefit of more stable $\mathrm{M}_{23} \mathrm{C}_{6}$ carbide as shown in Figs. $5 \mathrm{a}$ and $6 a$. These findings are in accordance with the author's previous work $[14,48]$. The involved process of carbide growth is attributed to the diffusion of carbon atoms from $\gamma$-austenite and the diffusion of chromium and molybdenum atoms from $\delta$-ferrite to the $\delta / \gamma$ interfaces as reported by several authors [14]. This process created chromium and molybdenum depleted zones inside the $\delta$-ferrite reducing its chromium concentration from $27 \mathrm{wt} \%$ to $7 \mathrm{wt} \%$ during aging for very long duration at $550{ }^{\circ} \mathrm{C}$ as shown in Fig. 11. The chromium-depleted zone was also generated by intergranular $\gamma / \gamma$ carbide and chromium concentration in the vicinity of grain boundaries and which continues to decrease as the growth process of carbide continues to operate. The replenishment occurs when the chromium-consuming process is slowed sufficiently due to the decrease of the carbon activity in the austenite. The dechromisation and rechromisation phenomena were illustrated by the chromium profiles shown in Fig. 10. Aging at higher temperatures accelerates the nucleation and the growth of carbides at the $\gamma / \gamma$ grain boundaries and at the $\delta / \gamma$ interface, resulting in a significant decrease of the carbon content of austenite. Therefore, the chromium-rich and molybdenum-rich intermetallic phases, such as $\sigma, \chi$ and $\mathrm{R}$, and requiring higher energy sites as reported in previous works $[14,48]$, precipitate at the $\mathrm{M}_{23} \mathrm{C}_{6} / \gamma$ and $\mathrm{M}_{23} \mathrm{C}_{6} / \delta$ interfaces as shown in Fig. 7a. Laves phase $\eta$ was also observed at the $\mathrm{M}_{23} \mathrm{C}_{6} / \gamma$ interface. It also exists within austenite grains through prolonging the aging period at $650{ }^{\circ} \mathrm{C}$. The growth of these phases was likely to be performed at the expense of intergranular carbides which become less apparent compared to larger plates of $\sigma$-phase. However, the chromium depletion related to carbides is more significant than that resulting from intermetallic phases although they are also chromium-rich phases. Sahlaoui et al. [53] have demonstrated that nucleation of $\sigma$-phase required high energy sites and a chromium level higher than $14 \mathrm{wt} \%$. The correlation between microstructure and the DOS, coupled with attack morphologies as in accordance with the ASTM A262 practice A standard, revealed that the IGC sensitization-desensitization are only controlled by the level and the extent of chromium depletion resulting from the nucleation and the growth of $\mathrm{M}_{23} \mathrm{C}_{6}$ carbide at the austenite grain

Table 5

Correlation between chromium depleted zones and IGC sensitization evaluated by the DOS values and IGC morphologies.

\begin{tabular}{|c|c|c|c|c|c|c|}
\hline \multirow{2}{*}{\multicolumn{2}{|c|}{ Aging conditions }} & \multicolumn{3}{|c|}{ Depleted zones characteristics } & \multirow{3}{*}{$\begin{array}{l}\text { IGC } \\
\text { Morphology }\end{array}$} & \multirow{3}{*}{$\begin{array}{l}\text { DOS (\%) } \\
\text { Resulting from DL-EPR tests }\end{array}$} \\
\hline & & \multicolumn{2}{|c|}{$\begin{array}{l}\text { Chromium level } \\
\text { (wt. \%) }\end{array}$} & \multirow{2}{*}{$\begin{array}{l}\text { Extend of depleted zone (nm) } \\
\mathrm{W}_{\mathrm{D}}\end{array}$} & & \\
\hline Temperature $\left({ }^{\circ} \mathrm{C}\right)$ & Duration (h) & $\gamma / \gamma$ & $\delta$ & & & \\
\hline Annealed state & & 17.4 & 27 & 0 & Step & 0 \\
\hline \multirow[t]{4}{*}{550} & 1000 & 17.4 & 17.5 & - & Step & 0 \\
\hline & 10000 & 11 & 8.1 & 42 & Dual & 2.5 \\
\hline & 30000 & 10.5 & 8.8 & 110 & Ditch & 7.2 \\
\hline & 80000 & 12 & 10 & 215 & Ditch & 38.4 \\
\hline \multirow[t]{4}{*}{600} & 500 & 13 & 13 & - & Step & 0 \\
\hline & 1000 & 11.8 & 7.7 & 72 & Dual & 2.5 \\
\hline & 10000 & 12.8 & 9 & 103 & Ditch & 17.4 \\
\hline & 30000 & 13.2 & $14^{\mathrm{a}}$ & 0 & Ditch & 2.5 \\
\hline \multirow[t]{3}{*}{650} & 100 & 14 & 10 & 0 & Dual & 2.8 \\
\hline & 1000 & 12.1 & 13.4 & 104 & Ditch & 33 \\
\hline & 10000 & 16.5 & $16^{\mathrm{a}}$ & 0 & Step & 0 \\
\hline 700 & 100 & 11.8 & $16^{a}$ & - & Ditch & 17 \\
\hline
\end{tabular}

${ }^{\mathrm{a}}$ Chromium level of regenerated austenite $\left(\gamma_{\mathrm{r}}\right)$ resulting from total decomposition of $\delta$ ferrite during aging. 


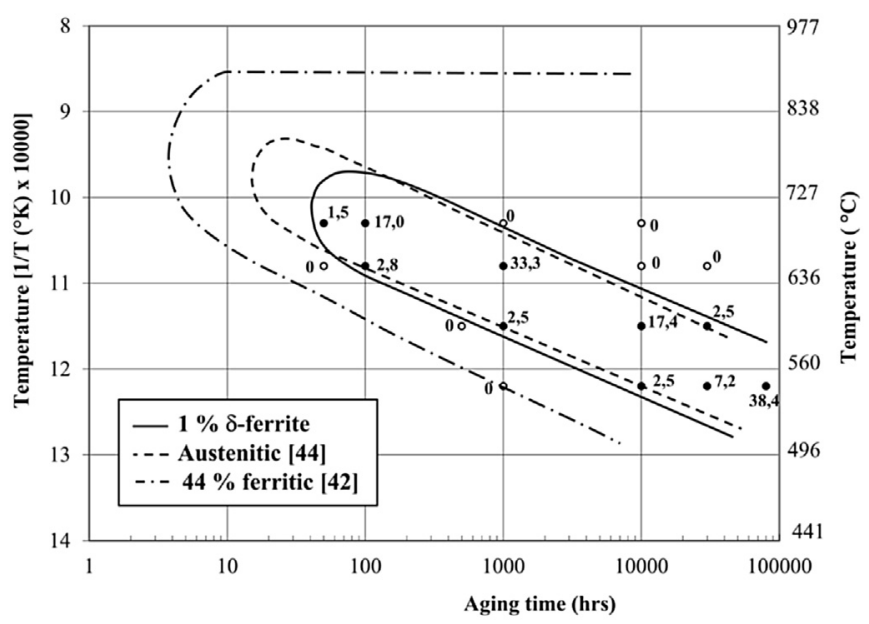

Fig. 15. Effect of ferrite content on the IGC sensitization of stainless steel derived from DL-EPR.

boundaries. It has been established that chromium depletion in the vicinity of austenite grain boundaries, below $12-13$ wt\% and extending over $100 \mathrm{~nm}$ in width sensitizes the AISI 316L with $1 \%$ of $\delta$-ferrite. However, the replenishment over $12-13$ wt\% of chromium leads to self-healing. Otherwise, the contribution of $\delta$-ferrite to IGC sensitization seems to be not effective or negligible. This result corroborates Guanshun et al.'s one [46], indicating that the DOS of Ti modified Super $304 \mathrm{H}$ is still insignificant during aging at $650{ }^{\circ} \mathrm{C}$ for a $\delta$-ferrite content below $3.9 \%$. Increasing the ferrite fraction to $6.1 \%$ strongly deteriorates the IGC resistance at the same aging conditions. Authors attributed this result to the small contribution to IGC sensitization of the limited depleted areas related to low fraction of $\delta$-ferrite. This tendency is clearly evidenced by Fig. 15, showing the superimposition of TTS curves corresponding to $0 \%$ [44] 1\% (this study) and 45\% [42] of $\delta$-ferrite. Concerning this study, the correlation between microstructure and the DOS values provides more explanation. Indeed, after aging at $550{ }^{\circ} \mathrm{C}$ for relatively short period of up to $1000 \mathrm{~h}$, the dechromisation into $\delta$-ferrite was not enough $(\mathrm{Cr} \geq 13 \mathrm{wt} \%)$ to provoke IGC, and therefore, the DOS remained less than $1 \%$. By prolonging aging at the same temperature to up to $10000 \mathrm{~h}$, the DOS was higher than $2 \%$ and the "ditch" structure was related to chromium-depleted austenitic grain boundaries as shown in Fig. 13. This means that the contribution of the low fraction of chromium-depleted areas related to $\delta$-ferrite and to DL-EPR response is negligible compared to that of the austenite grain boundaries areas. At higher temperatures, the $\delta$-ferrite totally disappears with the associated depleted zones, since the chromium content of the regenerated austenite $\gamma_{\mathrm{r}}$ $(\mathrm{Cr} \%=16)$ is approximately equal to that of the initial $\gamma$-austenite $(\mathrm{Cr} \%=17.4)$. Therefore, the IGC sensitization is exclusively controlled by the chromium-depleted zones related to austenitic structure. That is why the TTS diagram of fully austenitic stainless steel completely coincides with that of low ferrite content austenitic stainless steel at very long aging durations, as shown in Fig. 15. In addition, chromium carbide $\left(\mathrm{M}_{23} \mathrm{C}_{6}\right)$ and the associated chromium-depleted zones near the $\gamma / \gamma$ grain boundaries are considered as the main element responsible for IGC sensitization of AISI $316 \mathrm{~L}$ with $1 \% \delta$-ferrite since $\sigma$-phase appears at aging durations longer than $10000 \mathrm{~h}$ at temperatures higher than $650^{\circ} \mathrm{C}$. These last parameters correspond to the occurrence of the rechromisation process which is in accordance with previous modeling and experimental work devoted to fully austenitic stainless steels [54]. Using TTS diagrams and equation (1) [13], the CCR to prevent IGC sensitization of AISI $316 \mathrm{~L}$ with $1 \% \delta$-ferrite $(24 \mathrm{~K} / \mathrm{h})$ has been determined and compared to that of AISI 316L fully austenitic stainless steel $(86 \mathrm{~K} / \mathrm{h})$. The lower value of CCR corresponding to AISI 316L with $1 \% \delta$-ferrite is rather assigned as a beneficial effect of higher nitrogen level $(\mathrm{N}=0.08 \% \mathrm{wt})$ when compared to that of AISI $316 \mathrm{~L}(\mathrm{~N}=0.035 \% \mathrm{wt})$, as reported by previous works [11-13].

\section{Conclusion}

Aging at temperatures ranging between 550 and $700{ }^{\circ} \mathrm{C}$ for periods varying from $50 \mathrm{~h}$ to $80000 \mathrm{~h}$ modifies the microstructure and the IGC behavior of austenitic stainless steel AISI 316L with $1 \%$ $\delta$-ferrite. The microstructural changes occur faster in ferrite than in austenite. The TTP diagram, constructed on the basis of TEM examination, outlines that precipitation processes are thermally active and controlled by chromium diffusion mechanism. The precipitation of chromium-rich and molybdenum-rich phases such as $\mathrm{M}_{23} \mathrm{C}_{6}$ carbide FK, $\eta, \sigma, \chi$ and $\mathrm{R}$, generates a chromium-depleted area in ferrite and in the vicinity of austenite grain boundaries. However, the corrosion behavior of aged steel, assessed by DL-EPR tests, is only affected by the $\gamma / \gamma \mathrm{M}_{23} \mathrm{C}_{6}$ carbide precipitation and the associated chromium depletion zones. IGC sensitization occurred, in the conditions of this study, for DOS $\geq 1 \%$ when the chromium concentration falls below the critical value of $13 \mathrm{wt} \%$ and a width of the depleted zone higher than $100 \mathrm{~nm}$. The self-healing is achieved when the critical value of chromium is recovered. The low ferrite content, recommended for hot cracking resistance and its decomposition products such as $\sigma, \chi$ and $\mathrm{R}$ during aging, does not alter the steel corrosion behavior since the TTS diagram remained coincident with that of fully austenitic stainless steel. The CCR preventing any risk of IGC sensitization, and calculated from the TTS diagram and using Dayal method, is found to be $24 \mathrm{~K} / \mathrm{h}$.

\section{References}

[1] M. Cindra Fonseca, I.N. Bastos, E. Baggio-Saitovitch, D.R. Sánchez, Characterization of oxides of stainless steel UNS S30400 formed in offshore environment, Corros. Sci. 55 (2012) 34-39.

[2] C. Jullien, T. Bénézech, B. Carpentier, V. Lebret, C. Faille, Identification of surface characteristics relevant to the hygienic status of stainless steel for the food industry, J. Food Eng. 56 (2003) 77-87.

[3] Y. Ke, R. Yibin, Nickel-free austenitic stainless steels for medical applications, Sci. Technol. Adv. Mater. 11 (2010) 014105.

[4] M. Talha, C.K. Behera, O.P. Sinha, A review on nickel-free nitrogen containing austenitic stainless steels for biomedical applications, Mater. Sci. Eng. C 33 (2013) 3563-3575

[5] E. Mohammadi Zahrani, A. Saatchi, A. Alfantazi, Pitting of 316L stainless steel in flare piping of a petrochemical plant, Eng. Fail. Anal. 17 (2010) 810-817.

[6] M. Milititsky, D.K. Matlock, A. Regully, N. Dewispelaere, J. Penning, H. Hanninen, Impact toughness properties of nickel-free austenitic stainless steels, Mater. Sci. Eng. A 496 (2008) 189-199.

[7] H. Sidhom, A. Ben Rhouma, C. Braham, J. Ledion, Préparation des surfaces et tenue à la corrosion localisée des aciers inoxydables austénitiques, Matér. Tech. $86\left(\mathrm{~N}^{\circ}\right.$ 9-10) (1998) 31-37.

[8] A.B. Rhouma, H. Sidhom, C. Braham, J. Lédion, M.E. Fitzpatrick, Effects of surface preparation on pitting resistance, residual stress, and stress corrosion cracking in austenitic stainless steels, J. Mater. Eng. Perform. 10 (2001) 507-514.

[9] G. Bai, S. Lu, D. Li, Y. Li, Influences of niobium and solution treatment temperature on pitting corrosion behaviour of stabilised austenitic stainless steels, Corros. Sci. 108 (2016) 111-124.

[10] B. Kartik, R. Veerababu, M. Sundararaman, D.V.V. Satyanarayana, Effect of high temperature ageing on microstructure and mechanical properties of a nickelfree high nitrogen austenitic stainless steel, Mater. Sci. Eng. A 642 (2015) 288-296.

[11] Y.J. Oh, J.H. Hong, Nitrogen effect on precipitation and sensitization in coldworked Type 316L(N) stainless steels, J. Nucl. Mater. 278 (2000) 242-250.

[12] R. Beneke, R.F. Sandenbergh, The influence of nitrogen and molybdenum on the sensitization properties of low-carbon austenitic stainless steels, Corros. Sci. 29 (1989) 543-555.

[13] N. Parvathavarthini, R.K. Dayal, Time-temperature-sensitization diagrams and critical cooling rates of different nitrogen containing austenitic stainless steels, J. Nucl. Mater. 399 (2010) 62-67.

[14] H. Sidhom, Etude de l'évolution structural au cours du vieillissement de deux aciers inoxydables austénitiques, et de son influence sur les propriétés 
mécaniques et la corrosion inter-cristalline, University of Paris XI, Paris, 1990.

[15] A. Pardo, M.C. Merino, A.E. Coy, F. Viejo, M. Carboneras, R. Arrabal, Influence of Ti, $\mathrm{C}$ and $\mathrm{N}$ concentration on the intergranular corrosion behaviour of AISI 316Ti and 321 stainless steels, Acta Mater. 55 (2007) 2239-2251.

[16] K. Chandra, V. Kain, R. Tewari, Microstructural and electrochemical characterisation of heat-treated 347 stainless steel with different phases, Corros. Sci. 67 (2013) 118-129.

[17] H.S.I. Trigui, C. Braham, J. Lédion, La corrosion par piqûres d'aciers inoxydables austéno-ferritiques dans l'eau de mer synthétique - influence de la composition chimique et de la teneur inclusionnaire, matériaux et techniques, Hors séris, 1996, pp. 23-30.

[18] J. Verma, R.V. Taiwade, Dissimilar welding behavior of $22 \% \mathrm{Cr}$ series stainless steel with 316L and its corrosion resistance in modified aggressive environment, J. Manuf. Process. 24 (Part 1) (2016) 1-10.

[19] M. Ziętala, T. Durejko, M. Polański, I. Kunce, T. Płociński, W. Zieliński, M. Łazińska, W. Stepniowski, T. Czujko, K.J. Kurzydłowski, Z. Bojar, The microstructure, mechanical properties and corrosion resistance of $316 \mathrm{~L}$ stainless steel fabricated using laser engineered net shaping, Mater. Sci. Eng. A 677 (2016) 1-10.

[20] Y. Cai, Z. Luo, M. Feng, Z. Liu, Z. Huang, Y. Zeng, Effect of activator on mechanical properties and intercrystalline corrosion resistance of austenitic stainless steel weld, J. Mater. Process. Technol. 234 (2016) 243-248.

[21] C. Garcia, F. Martin, P. de Tiedra, Y. Blanco, M. Lopez, Pitting corrosion of welded joints of austenitic stainless steels studied by using an electrochemical minicell, Corros. Sci. 50 (2008) 1184-1194.

[22] M. Dadfar, M.H. Fathi, F. Karimzadeh, M.R. Dadfar, A. Saatchi, Effect of TIC welding on corrosion behavior of 316L stainless steel, Mater. Lett. 61 (2007) 2343-2346.

[23] C. Braham, A. Ben Rhouma, J. Lédion, H. Sidhom, Effect of machining conditions on residual stress corrosion cracking of 316L SS, Mater. Sci. Forum 490-491 (2005) 305-310.

[24] J.B. Cai, C. Yu, R.K. Shiue, L.W. Tsay, Stress corrosion cracking of austenitic weld deposits in a salt spray environment, J. Nucl. Mater. 465 (2015) $774-783$.

[25] K.N. Lyon, T.J. Marrow, S.B. Lyon, Influence of milling on the development of stress corrosion cracks in austenitic stainless steel, J. Mater. Process. Technol. 218 (2015) 32-37.

[26] J.Z. Lu, K.Y. Luo, D.K. Yang, X.N. Cheng, J.L. Hu, F.Z. Dai, H. Qi, L. Zhang, J.S. Zhong, Q.W. Wang, Y.K. Zhang, Effects of laser peening on stress corrosion cracking (SCC) of ANSI 304 austenitic stainless steel, Corros. Sci. 60 (2012) $145-152$.

[27] A.Y. Kina, V.M. Souza, S.S.M. Tavares, J.M. Pardal, J.A. Souza, Microstructure and intergranular corrosion resistance evaluation of AISI 304 steel for high temperature service, Mater. Charact. 59 (2008) 651-655.

[28] A. Abou-Elazm, R. Abdel-Karim, I. Elmahallawi, R. Rashad, Correlation between the degree of sensitization and stress corrosion cracking susceptibility of type 304H stainless steel, Corros. Sci. 51 (2009) 203-208.

[29] M. Matula, L. Hyspecka, M. Svoboda, V. Vodarek, C. Dagbert, J. Galland, Z. Stonawska, L. Tuma, Intergranular corrosion of AISI 316L steel, Mater. Charact. 46 (2001) 203-210.

[30] M. Terada, D.M. Escriba, I. Costa, E. Materna-Morris, A.F. Padilha, Investigation on the intergranular corrosion resistance of the AISI 316L(N) stainless steel after long time creep testing at $600^{\circ} \mathrm{C}$, Mater. Charact. 59 (2008) 663-668.

[31] N. Yoshikuni, N. Kazutoshi, I. Mitsunori, Influence of delta-ferrite on sensitization of the austenitic stainless steel weld metal, Q. J. Jpn. Weld. Soc. 9 (1991) 415-422.

[32] F. Wilson, Mechanism of intergranular corrosion of austenitic stainless steels-literature review, Br. Corros. J. 6 (1971) 100-108.

[33] J.J. Heger, J.L. Hamilton, Effect of minor constituents on the intergranular corrosion of austenitic stainless steels, Corrosion 11 (1) (1955) 22-26.
[34] T. Ogawa, E. Tsunetomi, Hot cracking susceptibility of austenitic stainless steels, Weld. Res. Suppl. 61 (1982) 82s-93s.

[35] J.C. Lippold, W.F. Savage, Characterization of weld solidification cracking in a duplex stainless steel weldments: Part III - the effect of solidification behavior on hot cracking susceptibility, Weld. Res. Suppl. 61 (1982) 88S-96S.

[36] P. Manning, D. Duquette, W. Savage, Technical Note: the effect of retaine ferrite on localized corrosion in duplex 304L stainless steel, Weld. J. (1980) 260-262.

37] C.L. Lai, L.W. Tsay, W. Kai, C. Chen, The effects of cold rolling and sensitisation on hydrogen embrittlement of AISI 304L welds, Corros. Sci. 52 (2010) 1187-1193.

[38] ASTM A262-10, Standard Practices for Detecting Susceptibility to Intergranular Attack in Austenitic Stainless Steels, New York, 2010.

[39] Report No. NF EN ISO 3651-2, AFNOR, Cedex, France, 1998

[40] Report No. NF EN ISO 3651-1, AFNOR, Cedex, France, 1998

41] ASTM A262-02a (Reapproved 2008), Standard Practices for Detecting Susceptibility to Intergranular Attack in Austenitic Stainless Steels, ASTM, PA 2008.

[42] T. Amadou, H. Sidhom, C. Braham, Double loop electrochemical potentiokinetic reactivation test optimization in checking of duplex stainless stee intergranular corrosion susceptibility, Metall. Mater. Trans. A 35 (2004) 3499-3513.

43] H. Sidhom, T. Amadou, C. Braham, Evaluation by the double loop electrochemical potentiokinetic reactivation test of aged ferritic stainless steel intergranular corrosion susceptibility, Metall. Mater. Trans. A 41 (2010) 3136-3150.

[44] H. Sidhom, T. Amadou, H. Sahlaoui, C. Braham, Quantitative evaluation of Aged AISI 316L stainless steel sensitization to intergranular corrosion: comparison between microstructural electrochemical and analytical methods Metall. Mater. Trans. A 38 (2007) 1269-1280.

[45] G.H. Aydoğdu, M.K. Aydinol, Determination of susceptibility to intergranular corrosion and electrochemical reactivation behaviour of AISI 316L type stainless steel, Corros. Sci. 48 (2006) 3565-3583.

[46] G. Bai, S. Lu, D. Li, Y. Li, Intergranular corrosion behavior associated with deltaferrite transformation of Ti-modified Super304H austenitic stainless steel, Corros. Sci. 90 (2015) 347-358.

[47] C. Garcia, M.P. de Tiedra, Y. Blanco, O. Martin, F. Martin, Intergranular corrosion of welded joints of austenitic stainless steels studied by using an electrochemical minicell, Corros. Sci. 50 (2008) 2390-2397.

48] H. Sidhom, R. Portier, An icosahedral phase in annealed austenitic stainless steel? Philos. Mag. Lett. 59 (1989) 131-139.

[49] D. Carron, P. Chemelle, D. Michel, M.J. Hytch, R. Portier, Icosahedral related precipitation at a nanometric scale in a superferritic steel, J. Non Cryst. Solids 153-154 (1993) 473-477.

[50] K.W.A.L. Pryce, Practical estimation of composition balance and ferrite content in stainless steels, Iron Steel Inst. 195 (1960) 415-417.

[51] W. Jolly, C. Toffolon-Masclet, J.M. Joubert, B. Marini, F. Porcher, G. André, F. Cortial, P. Petit, S. Ringeval, In situ monitoring of isothermal phase transformation in two Nb stabilized austenitic stainless steels (316Nb) by neutron diffraction, J. Alloys Compd. 688 (Part B) (2016) 695-702.

[52] S.-M. Yang Y.-C. Chen, C.-H. Chen, W.-P. Huang. D.-Y. Lin, Microstructura characterization of $\delta / \gamma / \sigma / \gamma 2 / \chi$ phases in silver-doped 2205 duplex stainless steel under $800^{\circ} \mathrm{C}$ aging, J. Alloys Compd. 633 (2015) 48-53.

[53] H. Sahlaoui, H. Sidhom, Experimental investigation and analytical prediction of $\sigma$-phase precipitation in AISI 316L austenitic stainless steel, Metall. Mater. Trans. A 44 (2013) 3077-3083.

[54] H. Sahlaoui, K. Makhlouf, H. Sidhom, J. Philibert, Effects of ageing conditions on the precipitates evolution, chromium depletion and intergranular corrosion susceptibility of AISI 316L: experimental and modeling results, Mater. Sci. Eng. A 372 (2004) 98-108. 